\title{
Aydınlar, Akademisyenler ve Entelektüeller: Savaş Bitti Şiirine Farklı Bir Bakış
}

\author{
Mehmet Zahit Tiryaki*
}

"Gün geçtikçe daha iyi anlıyorum;

Türk entelektüeli, Türk aydını, Türk ülkesi denilen bu zengin ve ıssız dünya içinde bir garip yalnız bir kişidir. Bir münzevi mi? Hayır; bir acayip yaratık demeliyim. Öyle ya, bir insan tasavvur edin ki hangi ırktan, ne cinsten olduğu belli değildir. Kendi vatanı addettiği memleketin dibine doğru ilerledikçe kendi kökünden uzaklaştığını hissediyor. Hissetmese de bize etrafında hasıl olan boşluk, soğuk ve itici hava, ona her an kendi toprağından sökülmüş bir aykırı, bir acayip nebat olduğunu bildiriyor."

(Yakup Kadri, Yaban)

Rivayete göre analitik gelenekte eğitim görmüş bir filozof, Orta Çağ felsefesiyle ilgili bir seminerde öğrencilere, bir entelektüel tarihçinin otomobil almak için ikinci el satış yapan bir galeriye gittiğinde neden çabucak ilk gördüğü aracı satın alıp binip gittiğine çok şaşırdığını söyler. Orta Çağ entelektüel tarihine ilişkin ertesi günkü bir diğer seminerde ise aynı öğrenci grubu filozofun söylediklerini tarihçiye aktarırlar. Bu sefer entelektüel tarihçi kendisinin de bazı analitik filozofların aynı galeriye gidip benzer şekilde gelişigüzel bir otomobil seçmelerine ve zamanlarını otomobilin farlarından birini cilalayıp parlatmakla meşgul olmalarına şaşırdığını söyler. Rivayeti aktaran, buradaki örneklerin tarihçiler ile analitik geleneğe mensup filozofların yapmaya çalıştıkları şey arasındaki farkı anlamada rol oynadığı yorumunda bulunur. Buna göre filozof Orta Çağ yazarının görüşlerini kendi zamanının terimlerine ve felsefi meselelerine tercüme ederken; entelektüel tarihçi kendi gününün düşüncesini geçmişteki düşünürler tarafından üretilmiş teorilerin, görüşlerin felsefi problemlerin etkileri ya da en azından sonuçları olarak görür (Tachau, 2006, s. 2). Bu örnek üzerinden gidilmesi durumunda ilk anda akla gelen sorular şunlar olacaktır: Hakiki bir düşünsel etkinliği gerçekleştirecek olan tam olarak hangi nitelikte olacaktır? Bu kişiler kimi zaman amatörce gözüken, insana özgü yönelim ve hakiki arayışların yön verdiği sorumlulukla mı yoksa uzman ve profesyonelce kaygıların baskın olduğu kurumsal gerekliliklerle mi hareket edeceklerdir? Bu kişilerin gidip ilmî ve fikrî bir alışverişte bulunacakları, aidiyet ve mensubiyet duyacakları bir yer sorunu var mıdır, varsa bu yer neresidir? Son olarak da düşünsel etkinliğin nihai gerekçesi salt keyif ve zevk değilse ne olacaktır? Dolayısıyla bu örnek buradaki sorularda ifade edilen meselelerle yüzleşmekte olan Türk düşünce hayatı açısından oldukça önemli ve kullanışlı

* Arş. Gör., İstanbul Medeniyet Üniversitesi, Felsefe Bölümü.

İletişim: tiryakizahid@gmail.com. Adres: İstanbul Medeniyet Üniversitesi, Edebiyat Fakültesi, Felsefe Bölümü, Ünalan Mah. Ünalan Sok. D-100 Karayolu yanyol, Üsküdar, İstanbul. 
ögeler içermektedir. Her şeyden önce, katettiğimiz ilmî, fikrî, düşünsel süreçte karşımızda bir şekilde aydın, akademisyen, entelektüel ya da mütefekkir, düşünür gibi yeni tipler ortaya çıkmaktadır. Tartışmanın bir ucu, hakiki bir düşünsel etkinliğin bu tiplerden hangisi ile nitelikli bir şekilde gerçekleştirilebileceği sorusu bağlamında merkezîleşmektedir. Zira düşünsel etkinliğin ham maddesini teşkil eden geçmiş biraz da bu ve benzeri tipteki insan teklerinin şimdide ama geleceğe doğru nasıl konumlandıkları sorusuyla bir anlam kazanacaktır. Aynı zamanda bu düşünce etkinliğinin bireysel ve kurumsal yönleriyle ilgili problemler de tartışmaların önemli bir ayağını oluşturmaktadır. Bunu takip eden bir diğer problem ise söz konusu tiplerin evrensellik ve yerellik arasındaki hatta hangi düzlemde konumlanacakları, onların aidiyet ve mensubiyetlerinin nereye olacağıdır. Bu tartışmadaki temel yönelimlerin de iki istikamette seyrettiğini söyleyebiliriz. Uçlardan birisi aydın, akademisyen ve entelektüeli daha evrensel ve geniş bir kategoriye yerleştirip pür bilimsel ve felsefi bir tutumu onların rolü ve işlevi olarak görürken, diğer taraf aydın, akademisyen ve entelektüelin daha millî bir karakteri olması gerektiğine işaret etmektedir. Bu ve benzeri sorunlarla ilişkili son bir tartışma alanı söz konusu tiplerin kendileri ve ait oldukları toplumla ilgili eylemsel sorumluluklarının, devlet, siyaset ve iktidar gibi mekanizmalarla ilişkilerinin ne istikamette seyredeceği hakkındadır.

Özü itibarıyla modern Batı düşüncesi bağlamında ortaya çıkmış yeni bir tip olarak aydın, akademisyen ya da entelektüelin kimliğine, bireysel ve kurumsal rolüne, evrenselliğine ve yerelliğine, eylemsel sorumluluğuna ilişkin tartışmaların da bu anlamda öncelikle çağdaş Batı düşüncesinde başlamış ve yürütülüyor olması kadar tabii bir şey olmasa gerektir. Bu tartışmalar daha çok Antonio Gramsci'nin (1937) Hapishane Defterleri ile Aydınlar ve Toplum, Julien Benda'nın (1956) Aydınların Ihaneti, J. Paul Sartre'ın (1980) Aydınlar Üzerine (ya da Aydınların Savunusu), A. W. Gouldner'in (1980) Entelektüelin Geleceği, Michel Foucault'nun (1984) Entelektüelin Siyasi Işlevi, Edward Shils'in (1995) The Intellectuals and Powers and Other Essays, Edward Said'in (2003) Entelektüel, Zygmunt Bauman'ın Yasakoyucular ve Yorumcular, Noam Chomsky'nin Modern Çağda Entelektüellerin Rolü gibi belirli isimlerin temel metinleri üzerinden yapılmaktadır. ${ }^{1}$

Aydın ve entelektüellerle ilgili tartışmaların Türkiye ayağı ise çoğunlukla Ziya Gökalp, Mümtaz Turhan, Nurettin Topçu, Sabri Ülgener, Erol Güngör, Cemil Meriç gibi isimlerin görüşleri üzerinden yürütülür. Bu isimlerden aydın ve entelektüel meselesi üzerinde düşünmüş ve kalem oynatmış olan Sabri Ülgener, Cemil Meriç gibi bazı isimlerde meselenin daha çok Batılı literatürdeki aydın ve entelektüellere ilişkin tartışmalar bağlamında ele alındığı görülür (Çağan, 2005 c, s. 309-326). Söz konusu kavramların Tanzimat'a uzanan yakın geçmişine ve nadiren Selçuklu-Osmanlı tarihi arka planına kabaca işaret eden bazı çalışmalar hariç Türkçedeki çağdaş yorumlar büyük oranda yabancı literatürdeki tartışmalar üzerinden şekillenir. Belki modern bir tip olarak aydın ve entelektüellere ilişkin bir tartışma bağlamında bu yazıda da yeri geldikçe başvurulacak olan temel isimlerin ana metinlerine müracaat tabii bir zorunluluktur. Fakat en genel anlamda bilgi ve düşünceyle ilgili farklı tiplerin başta kendileri olmak üzere ait ve mensup oldukları toplumla, kurumlarla, milletle, siyasetle ve dünyayla ilişkileri ile ilgili incelemelerin tarihsel arka planının daha gerilere doğru gitmesi

1 Burada zikredilen isimlerin de yer aldığı, entelektüellerle ilgili tartışmayı sosyolojik açıdan inceleyen bir çalışma için bk. Genç (2006). 
gerektiği açıktır. Zira özellikle Batılı literatürde aydın ve entelektüellere yönelik tartışmaların Orta Çağlara ve hatta Antik Yunan'a kadar gidebilecek nitelikte ve felsefi bir derinlikte yapıldığı dikkat çeker. ${ }^{2}$ Bizdeki tartışmalar ise hâlâ sağ ve sol aydınlar gibi yapay ayrımlar, Batı́nın evrensel bilimi ve ileri demokrasisine kıyasla Türk aydınının ümitsiz vaka oluşu gibi tasvirler eşliğinde yürütülmektedir. Elbette istisna niteliği taşıyan çalışmalar olmakla birlikte kavramların en fazla Tanzimat'a kadar gidebildiği görülür. Fakat daha öncesi çoğunlukla olumsuz bir tasvirle anılır. Bu tasvirde de ya dinin ya da klasik Selçuklu-Osmanlı devlet zihniyetinin zamanın bilgi ve düşünceyle ilgili en önde gelen tipi olarak görebileceğimiz ulemayı kendi amaçları doğrultusunda kullanmasının eleştirel anlamda bir bilgin tipinin ortaya çıkmasına engel olduğu şeklindeki iddialar etkili olmuş görünür. ${ }^{3}$ Bir bakıma daha aydın ve entelektüeller meselesinin tartışı Imaya başlandığı yer itibarıyla ortaya çıkıveren bir evrensellik-yerellik sorunumuz olduğu söylenebilir. Netice itibarıyla bu yazıda kısmen konu edilebilecek olan ve Türkiye özelinde meseleyi tartışan düşünürler hakkındaki biyografi-monografi tarzındaki çalışmaların sayısında bir artış gözlenmekledir. Fakat tartışmanın ilk ayağını teşkil eden üniversite, aydın, akademisyen ve entelektüel hakkındaki genel nitelikli, kapsayıcı ve teorik çalışmalar henüz yapılmamış görülmektedir.

Bu yazının iddiası mevcut tartışmaları bütünüyle tasvir etmek olmadığı gibi bu tartışmalara ilişkin derinlikli teorik bir yaklaşım sunmak da değildir. Zira bu iddiaların ilki gereksiz, ikincisi ise bu yazının da yazarın da imkânının çok üstündedir. Burada mevcut tartışmalarda öne çıkan bir grup temel problem alanı İsmet Özel'in bu tartışmalar bağlamındaki düşüncelerini sorgulamak için aracı ve anahtar olarak kullanılacaktır. Onun görüşleri de yeri geldiğinde farklı metinlerine atıf yapılmakla birlikte bu yazı bağlamında Savaş Bitti şiiri özelinde dikkate alınacaktır. İsmet Özel'in söz konusu şiiri, hem şiirin akışı hem de içeriğindeki kimi metaforlar itibarıyla bir aydın ya da entelektüelin, bireysel ve toplumsal, düşünsel ve eylemsel sorumluluğu eşliğinde bir düşünce etkinliğinin nasıl olabileceği bağlamında yorumlanmaya müsait zengin çağrışımlar sunmaktadır. Bu itibarla ilk kısımda aydın ve entelektüelin kimliği, ikinci kısımda aydın ve entelektüel tipi ile uzman akademisyenler arasındaki ilişkiler ve ayrımlar, üçüncü kısımda aydın ve entelektüelin evrensellik ve yerellik arasındaki konumu, dördüncü kısımda ise aydın ve entelektüelin en geniş anlamılla eylemsel sorumluğuna ilişkin tartışmalar İsmet Özel'in Savaş Bitti şiirindeki kimi vurgular eşliğinde yorumlanacaktır.

2 Bununla ilgili olarak Mark Lilla'nın Platon üzerinden konuyu inceleyen "Syrakusa'nın Çekiciliği" başlıklı makalesi iyi bir örnek teşkil eder (Lilla, 2002, s. 136-150). Le Goff ise entelektüel teriminin sınırları belirlenmiş bir ortama yani okul hocalarının ortamına işaret ettiğini söyleyerek terimin anlamını genişletir ve terimin bu bağlamda Avrupa Orta Çağı'ndaki görünümlerini inceler (Le Goff, 1994, s. 15-16). Modern entelektüelin tarihsel arka planına ilişkin olarak ayrıca bk. Konuk (2005, s. 73-86).

3 Türkiye'de bu meselelerle ilgili tartışmaları esas itibarıyla iki ana grupta toplayabiliriz. Bunlardan ilki aydın ve entelektüelle ilgili meseleleri doğrudan yukarıda kısmen zikredilen çağdaş Batılı literatür üzerinden fakat Türkiye özelinde tartışmaktadır. Doğu-Batı dergisinin Akademi ve İktidar, Türk Düşünce Serüveni: Araftakiler, Türk Düşünce Serüveni: Akademidekiler, Türk Düşünce Serüveni: Geç Aydınlanmanın Erken Aydınları, Entelektüeller-I, Entelektüeller-II, Entelektüeller-III başlıklı; Cogito dergisinin Entelektüeller Gerekli midir? başlıklı özel sayılarındaki, Entelektüel ve İktidar başlıklı derlemedeki çoğu metni bu bağlamda zikredebiliriz. İkinci kategori ise işaret edildiği üzere Türkiye özelinde meselenin tarihsel arka planına gitmeyi deneyen fakat bunu yukarıda işaret edilen temel sorunlardan kurtulamamış bir dil kullanarak yapan metinlerdir. Buna ilişkin bazı örnekler için bk. Arslan (2002, s. 208-213); Aydın (2005, s. 50-56, 66-70); Şan (2005, s. 275-304). 


\section{Aydın, Akademisyen ve Entelektüel ya da Çağdaş Bir Tip Olarak Ibn-i Filip}

En geniş anlamıyla entelektüel, her ne kadar tarihsel özellikleri itibarıyla çeşitlilik gösterse de meslekleri, düşünmek ve düşüncelerini öğretmek olan kimselere gönderme yapmaktadır (Le Goff, 1994, s. 15-17). Entelektüel, kendisini diğer kentliler gibi bir zanaatkâr, bir lonca mensubu gibi hisseden ve yüklendiği mesleğin bilincinde olan, bilimin dolaşıma sokulması gerektiğini düşünen kimsedir (Le Goff, 1994, s. 84-85).

Marksist bakış açısıyla entelektüellik hakkındaki literatür açısından önemli bir yeri olan Antonio Gramsci, entelektüelin iki sınıf hâlinde incelenebileceğini söyler. Bu sınıflardan ilki, onun geleneksel entelektüeller olarak adlandırdığı kimseler iken ikincisi, organik entelektüellerdir. İlk grup adından da anlaşılacağı üzere öğretmenlik, papazlık, idarecilik, bilginler, bilim adamları, teorisyenler, felsefeciler gibi daha geleneksel kurumlarda geleneksel rollerini devam ettiren kimselere gönderme yapar. Oysa organik entelektüeller sınıfı, topluma ve piyasaya aktif olarak katılan entelektüellere imada bulunur (Gramsci, 1983, s. 34). 19. yüzyılın sonlarında ortaya çıkmış entelektüeller sınıfına yönelik ilk önemli eleştirileri getirenlerden birisi olan Julien Benda'ya göre ise aydın, faaliyetleri temelde pratik amaçların yerine getirilmesine dayanmayan, sanat, bilim veya metafizikten zevk alan, maddi olmayan şeylerin peşinde olan, kendi yurdunu bu dünya olarak görmeyen kimselerdir (Benda, 2006, s. 37-38). Benda'nın aydını, Gramsci'nin organik entelektüellerine karşıt ve geleneksel entelektüellerine de bir miktar uymakla birlikte onları aşan, seçkin ve yüksek karakterli, özünde pratik amaçlar gütmeyen bir sınıfın bilim, sanat ve metafizik uğraşılarına imada bulunuyor görünür. Edward Said, Gramsci'nin organik entelektüel tanımının topluma ve ilişkiler ağına daha fazla katılan bir entelektüel fikrine işaret ettiğini buna karşılık Benda'nın ise daha az sayıda insana entelektüellik payesi verdiğini söyler. Bununla birlikte Benda'nın entelektüelinin fildişi kulesine kapanmış konuşan bir kimse olmadığını aksine entelektüellerin gerçek bir metafizik tutkudan, adalet ve hakkaniyet ilkesinden hareketle yozlaşmayı eleştirdikleri, zayıfları savundukları ve baskıc otoriteye meydan okudukları zaman tam anlamıyla entelektüel olacaklarını söyler. Bu anlamıyla entelektüel güçlü bir birey, statükoya karşı çıkan bir muhaliftir (Said, 1995, s. 21-24). Sartre ise parçalanmış toplumların bir ürünü olarak gördüğü aydını pratik bilgi uzmanları dediği kimselerden ayırır ve onları pratik gerçekliği araştırmasıyla egemen ideoloji arasındaki karşıtlığın bilincine varan kimseler olarak görür (Sartre, 2014, s. 37).

Foucault'nun büyük oranda siyasal ağırlıklı entelektüel tanımı ise "bilgisini, uzmanlığını ve hakikatle ilişkisini siyasi mücadele alanında kullanan kişi" şeklindedir (Keskin, 2000, s. 13). Entelektüele yüklediği tanım ve işlevin kendi iktidar analiziyle yakından ilişkili bir rolü olan Foucault (Keskin, 2000, s. 21) geleneksel ve evrensel entelektüel ile spesifik entelektüel arasında ayrım yapar. Artık ortaya çıkmış yeni iktidar ilişkileri içinde entelektüel, evrensel, bütüncül, herkes için geçerli bir hakikatin sahibi değildir. Yeni entelektüel, hastane, laboratuvar, üniversite gibi spesifik bir disiplin ya da kurumda çalışan kişidir. Onun bilgisi bütünsel, teorik bir bilgi değil spesifik, yerel bir alandaki uzmanlığıdır (Foucault, 2000, s. 46-53). Edward Said ise ortaya çıkan yeni ilişkiler ağının Benda'dan ziyade Gramsci'nin organik entelektüeline daha fazla imkân tanıdığını söyler (Said, 1995, s. 26-27). Said'in temel ayrımı ise profesyonel entelektüel ile amatör entelektüel arasındadır. O, profesyonelizm ile, "bir entelektüel olarak yapılan işi geçim kaygısıyla, sabah saat dokuz ile akşam saat beş arasında 
(bir gözü saatten ayırmadan, öbür gözle devamlı profesyonel davranış standartlarına uygun davranıp davranılmadığı üzerinde) yapılan bir şey diye düşünmeyi, denizi bulandırmama, kabul edilmiş paradigma ya da sınırların dışına çıkmama, pazarlanabilir ve öncelikle de prezentabl olmak uğruna apolitik ve "nesnel" biri hâline" gelmeyi kasteder. Said, profesyonelizmin karşııına ise amatörizm dediği şeyi koyar. Amatörizm, "kâr ya da ödül beklentisiyle değil tabloyu daha geniş çizmeye, belli çizgiler ve engeller arasında bağlantılar kurmaya duyulan aşk ve dinmek bilmez merakla, bir uzmanlık alanına kapatılmayı reddederek, belli bir meslekten olmanın insana getirdiği her türlü kısıtlamaya rağmen düşüncelere ve değerlere özen göstererek hareket etme isteğidir." (Said, 1995, s. 80-83). Ona göre entelektüel, ucuz formülleri, insan düşüncesini ve insanlar arası iletişimi kıskacı altına alan hazır klişeleri, muktedirlerin ve uzlaşmacıların söylediklerinde, yapıp ettiklerinde gözlenen olumlamaları kabullenmek istemeyen ve bu uğurda bütün varlığını ortaya koyan biridir (Said, 1995, s. 11-12, 37-38).

Entelektüel aynı zamanda biz ile öteki arasındaki öncü benin yalnızlığıdır (Çağan, 2005a, s. 15; Çağan, 2005b, s. 158-159). Entelektüelin her türlü aidiyetine rağmen kendisini biz şeklinde ifade etmekten sıkılıp her yerde ben olarak ortaya çıkma isteği, ondaki bu benlik iddiası ise kendini aşmak, kendinden fazlasını içermek yönünde bir niteliğe sahiptir. Her ne kadar kolektif bilincin ve eylemin karşısında gibi gözükse de ondaki benlik vurgusu nihai noktada genelin menfaatlerini de içeren bir niteliğe bürünür (Çağan, 2005b, s. 159).

Türkiye söz konusu olduğunda ulemadan entelektüele geçiş sürecinde ortaya çıkan yeni tipolojinin mevcut tiplerden hiçbirine de bütünüyle ait olamadığı dikkat çeker (Çağan, 2005c, s. 310-311). İsmet Özel'in eleştirileri, tam da bu geçiş dönemi aydın ve entelektüel tipine yönelik unsurlar ihtiva eder. Onun Savaş Bitti şiirinde eleştirel bir bağlamda yer verdiği İbn-i Filip karakteri, bu geçiş döneminin iki arada bir derede, zihniyet dünyası itibarıyla biraz Müslümanca biraz da seküler bir şekilde kendini var kılan aydın, akademisyen ve entelektüeller için çok kullanışı bir tanımlama ve eleştiri aracı olarak gözükür. Fakat o, meseleyi salt eleştiri düzeyinde bırakmayarak aydın ve entelektüelin kimliğinin ne olması gerektiğine ilişkin tekliflerde de bulunur. İsmet Özel, dünya olayları ve yeryüzünde insan mevcudiyeti konusunda çok temelli bilgilere sahip olan ama genel geçer yargılara göre hiç de aydın sayılmayacak kişilerin gerçekte aydın sayılmasından yana olduğunu ifade eder. Ona göre Müslüman olsun ya da olmasın içinde yaşadığı toplum ve yeryüzündeki insanın mevcudiyeti konusundaki tutumu tutarlı bilgilere, görüşlere sahip olan insan aydındır. Oysa bugün Türkiye'de yaşayan çok kimse, kendisine empoze edilmiş olan, kendisini şartlamış olan bilgileri esas saydığı için aydın olarak kabul edilmektedir (Özel, 1999a, s. 113). Bununla birlikte o, aydın kelimesinin çok dikkatli kullanılması gerektiğinin de farkında olarak okumuş gibi bir kelimenin tercihinden yana olduğunu söyler. Çünkü Türkiye'de oluşmuş bir entelijansiya söz konusu değildir fakat Türkiye'nin Osmanlıdan devraldığı bir okumuşluk sorunu vardır (Özel, 1999a, s. 231).

Aydın ve entelektüellerle ilgili değişik tanım ve tasniflere benzer bir değerlendirmeyi ve yeni bir teklifi İsmet Özel'de aklı yoranlar ile dinç akılılar arasında yapılan ayrımda buluruz. Şairin zihninde aklı yormak olumlu; dinç akıllılık ise olumsuz anlamlar taşır. Aklı yormak aklı takatten düşüren bir şeydir. Aklı yorulan ise dinç akıllı olamaz. Hâlbuki şairin dilinde insanların çoğunun dinç akıllı ve cehennemlik olduğu ifade edilir. Cehennemliğin burada isten- 
meyen, kötü bir şeyden kinaye olduğu açıktır. Zevahiri kurtaran okuryazar takımı akıllarını yormadıkları için genellikle dinç akılı bir görüntü çizerler.

İsmet Özel'in aklı yoranları aralarındaki bir denge noktası olarak gördüğü iki uç daha vardır. Bu uçlardan birisi aklı havada uçanlar diğeri aklı yerin dibine batıranlardır. Buna göre aklı havalarda uçanla rasyonalist, sistemci düşünürlerin; aklı yerin dibine batıranlar ile de rasyonalist ve idealist felsefeye yöneltilen eleştirilerin sahibi olan düşünürlerin kastedildiği söylenebilir (Özel, 2005, s. 64).

\section{Üniversite Mensubu Uzman Akademisyenler ile Gerçek Entelektüeller ya da Dinç Akılılar ile Aklı Yoranlar}

En temelde üniversite olmak üzere gerçek bir düşünsel ve entelektüel faaliyetin kurumsal yapılarla ve kurumsal yapılardaki tiplerle olan ilişkisi sıklıkla tartışılan bir husustur. ${ }^{4}$ Modern Batı düşüncesinde Schopenhauer (1860), üniversite bünyesindeki felsefi faaliyete en keskin eleştirileri yönelten isimlerden birisidir. Ona göre üniversitede felsefe eğitiminin çok temel bazı faydaları olmakla birlikte kürsü felsefesinin, bir meslek olarak felsefenin ve devlet güdümündeki felsefenin, özgür hakikat araştırması ile doğa ve insanlık adına yapılan felsefeye yönelik zararları da vardır (Schopenhauer, 2008, s. 39, 40-42, 83-84, 99-103). Schopenhauer, uzun sözcüklerle, karmaşık belagat oyunlarılla, işitilmedik deyimlerle, allamelik görüntüsü veren fakat anlaşılması güç bir jargonla yapılan sözüm ona felsefi etkinliği "dönen değirmen taşlarının tıkırtısını işitmeye fakat öğütülen unu görememeye" benzetir (Schopenhauer, 2008, s. 68-70).

Üniversite meselesine kafa yormuş isimlerden birisi olarak Heidegger ise Schopenhauer'e oranla üniversiteyi daha nötr bir kurum olarak görür ve içini doldurmaya çalışır. Üniversite sadece nesnel bilgi üretiminin aracı kurumu olarak değil bir halkın tarihsel-manevi dünyasının merkezindeki temel sorgulamanın kendisi aracılığıyla yapılabileceği kurum olarak da görülür (Heidegger, 2002, s. 47-48). Heidegger, ideal bilgi anlayışının öğrenciyi sadece nesnelliğe adamadığını aynı zamanda halkın tarihsel-manevi dünyasının ortasında temel ve basit sorgulamaya da adadığını dile getirir. Nesnelliğin kurulacağı yer de burasıdır (Heidegger, 2002, s. 48).

Foucault'nun yaklaşımında ise daha önceki ve sonraki kimi isimlerce entelektüelin muhalif ve eleştirel kimliğine karşılık daha çok bir eleştiri konusu olan akademisyen, uzman gibi tipler, belirli yerellikler içinde işlevsel olabilecek şekilde düşünülürler ve bütünüyle entelektüel nitelemesinin dışında bırakılmazlar.

Edward Said de akademisyenliğin veya başka herhangi bir profesyonel meşguliyetin entelektüel olmaya, entelektüelce katkı yapmaya doğrudan engel olup olmadığı meselesini tartışır ve üniversiteyi, akademiyi, belirli bir konuda uzmanlığı bütünüyle olumsuzlamaz. O, özünde heykelimsi, sabit, değişmez bir putu değil de bireysel bir işi, enerjiyi temsil ettiğini 
düşündüğü entelektüele yönelik tehdidin bu sebeple doğrudan akademiden veya ticarileşmeden gelmediğini, asıl tehdidin profesyonelizm dediği şeyden geldiğini söyler (Said, 1995, s. 80-81). Said, günümüz toplumunun da bazen ödüller vererek bazen de entelektüellerin çalışmalarını hor görerek, onlarla alay ederek, en çok da entelektüelin sadece kendi sahasında uzman olan bir profesyonel olması gerektiğini söyleyerek yazarın etrafını kuşattığını söyler (Said, 1995, s. 82). Said, entelektüelin karşılaştığı uzmanlaşma, bilirkişilik ve iktidara yakınlık gibi durumları profesyonelizmden kaynaklanan baskılar olarak görür ve ancak amatör bir tavırla bu baskıların aşılabileceğini söyler (Said, 1995, s. 83-89).

Üniversite eğitiminin doğrudan sorunlarıyla ilgili teknik bir incelemesinde Maclntyre da üniversite fikrinin içi doldurulması gereken nötr bir kurum olduğu kanaatinde gözükür. Bir üniversiteyi, üniversite yapmaktan çıkaran ve krize sokan durumu inceleyen Maclntyre üniversitelerde iki istikametten söz eder. İlk olarak disiplinlerdeki çoğalmanın neticesinde, ilim adamları ve üniversite hocaları bir taraftan uzmanlaşıp profesyonelleşirken aynı zamanda eğitim de veren araştırmacılara dönüşmüşlerdir. İkinci olarak ise akademisyenler mesleki başarıları özel bir disiplinle özdeşleşme derecesine bağlı olan uzmanlara dönüşmüşlerdir (MacIntyre, 2006, s. 1-2). Maclntyre'ın yazısının konumuzla ilgili önemli vurgularından birisi de aydınlar ve entelektüeller ile ilgili tartışmaların önemli bir noktası olarak üniversite ile toplumsal tartışma düzeyi arasındaki kopukluğun nasıl giderileceği yorumlarıdır. $\mathrm{O}$, mevcut kültürün uzmanlık sahasında ayrıntıları tartışırken ne kadar özenli ve dikkatli ise genel meseleler hakkındaki tartışmalarda da o kadar bayağı olduğunu söyler. Ona göre bu durumun nedeni, geniş eğitimli, merkezî meselelere dair ortak tartışma ölçülerine, tasavvuruna sahip bir kamunun yokluğudur. Dolayısıyla Macıntyre geniş kapsamlı bir müfredatın hem üniversiteye hem de topluma hizmet olacağını ifade eder (Maclntyre, 2006, s. 3-4). Macıntyre'ın bu düşünceleri, Türkiye'deki kırılmaya da işaret eder niteliktedir. Zira burada da büyük oranda üniversitelerde kendi uzmanlık alanlarında yazıp çizen akademisyenler ile bu yazıda bireysel ve toplumsal rolleri tartışılan ve üniversitelerdeki uzman akademisyenlere oranla daha genel düzlemde meseleleri tartışan aydın ve entelektüeller arasında irtibatsızlık söz konusudur. Her iki taraf için de diğer taraf daha değersizdir. Bu durum eğitim ve ihtisaslaşma kadar toplum için de bir rol icra etme vazifesi olan üniversitelerin bu işlevinin geçersiz kılınması ve toplumun en merkezî, en temel meselelerinin ortak ama kalitesi yüksek düzeyde bir tartışma alanında tartışılamadığı anlamına gelir. Her iki kanadın önemseyerek hararetle araştırdığı ve tartıştığı, hakkında yazılar yazdığı meseleler arasında ciddi oranda ilişkisizlikler söz konusudur.

Modern anlamıyla üniversite fikrine ve işleyişine yönelik eleştirilerin Türkiye ayağına intikal ettiğimizde meselenin büyük oranda üniversitenin maddi ve teknik imkânları bağlamında ele alındığı bir zihniyet analizinin pek yapılmadığı görülür. Nurettin Topçu (1975) ilk yazılarından itibaren meselenin teknik boyutunu inkâr etmemekle birlikte (Topçu, 1998a, s. 57-58) üniversite meselesinin zihniyet boyutunu da ciddiye alarak eleştiri ve tekliflerini dile getirmiş ilk isimler arasında bulunur. $\mathrm{O}$, meseleyi aydın ya da entelektüel gibi müstakil bir sınıf üzerinden tartışmaktan ziyade üniversite kurumu içinde tartışır ve üniversitenin ideal doğrultuda çalışabilmesinin felsefi ve tarihsel-toplumsal temellerini soruşturur. Topçu bir üniversite fikrinin üç temel ayağı olacağını ifade eder. Bunlardan birincisi üniversitenin bir milletin kültür merkezi ve millet kültürünün kaynağı olması; ikincisi, millet eğitim ve öğretiminin düzenleyicisi olması; üçüncüsü ise devletin realist yönü ile idealist yönü arasındaki 
ilişkiyi tesis etmesidir (Topçu, 1998a, s. 59-62). Topçu üniversiteler başta olmak üzere millet mektebinin bizzat kendi ellerimizle yıkılmasını "milletin istiklalini kazanmak fakat mektebin istiklalinden vazgeçmek" olarak görür. Dolayısıyla zamanımızın istiklal savaşı da bu cephede açılacak bir savaş olacaktır (Topçu, 1998b, s. 30, 35). Ona göre Batılılaşmak hevesiyle Batı dillerinde öğretim yapan okulların açılması millet ruhunu gömmek isteğiyle paraleldir (Topçu, 1998b, s. 30-32, 153). Bu şartları haiz üniversiteler Alman ve Amerikan piyasalarında yüksek maaş kollayan kurnazlara diploma dağıtmaya yarar (Topçu, 1998b, s. 31). Topçu, ağırlık merkezi hikmet ve felsefe, sanat ve edebiyat değil de fizik ve kimya gibi büyük oranda teknik bölümler olan Amerikan tarzı eğitim sisteminin ruh ve inanç kahramanları yerine meslek sahipleri, ustalar ve çok kazanmak isteyen adamlar yetiştireceğini söyler (Topçu, 1998b, s. 36, 40-42). Üniversitenin işlevini tam olarak yerine getirmediği noktalardan birisi de memleket ve milletin gerçek meselelerinin üniversite kapılarından içeri girip kendine yer bulamayışı (Topçu, 1998a, s. 145; Topçu, 1998b, s. 148), üniversitenin memleketin gerçek meseleleriyle doğrudan yüzleşmeyi sağlayacak ilimle meşgul olmak yerine ilmin tarihiyle ilgilenmesidir (Topçu, 1998b, s. 80-82). ${ }^{5}$

Üniversite fikrine ilişkin doğrudan bir tartışma yapmayan İsmet Özel'in ise kurumsal bir yapıdan ziyade tek tek fertler hâlinde milleti oluşturan insan unsurundan hareketle düşündüğünü söyleyebiliriz. İsmet Özel'in bu bağlamda eleştirdiği temel durumun kurumsal bir yapıda ve salt teorik, sistemci bir şekilde üretilen düşünce üretimi olduğu görülür (Özel, 1999a, s. 31-32). İsmet Özel'de düşünce belirli bir sorunlar yumağının ortasında gerçekleşen bir şey olup bu da ister istemez insanın içinde bulunduğu bütünün asli sorunlarıyla ciddiyetle yüzleştiği zaman düşünebileceği anlamına gelir. Ötesi Topçu'nun da işaret ettiği anlamda aşırı bir ilim/bilim tarihçiliğinden öteye gitmez. İsmet Özel, bir düşünce sistemine veya düşüncelerin sistemleştirilmesine yönelişin istenir bir şey olmadığını çünkü hedef gözeten bir hareketin nereye vuracağını, nereyi koruyacağını bilebilmek için tespitlere gerek duyduğunu fakat esnekliği azaltan ve sevk edilmeyi kolaylaştıran sistemleşmenin daha çok kurulu düzenlerin zimmetinde olduğunu ifade eder. Düşünce sistemlerine varmak da bir kültürün daha çok olgunluk, giderek çöküş dönemlerinin verimleri arasında yer alır. Yükselen bir kültür, gücünü toparlama aşamasında bulunan bir hareket ise neler yapılması gerektiğini yaparak bulup bilecektir (Özel, 1999a, s. 285). İnsanların arayan olmadıkça düşünen olamayacağını söyleyen İsmet Özel, düşüncenin zihnimizde yuvalanan ve bizi şöyle veya böyle yaşamaya icbar eden bir şey değil, "biz harekete geçtikçe bizi (ontolojik anlamda) tutan yani muhafaza eden ve fakat (bio-kültürel anlamda) tutuklamayan soyutlama yeteneğimiz" olduğunu söyler (Özel, 1999b, s. 197). ${ }^{6}$ Aslında İsmet Özel bütün bu vurgularda kurum-

5 Nurettin Topçu ile aynı zamanlarda üniversite sorununu inceleyen bir diğer isim Üniversite Problemi (1967) ve Maarifimizin Ana Davaları ve Bazı Hâl Çareleri (1954) başıııı eserleriyle Mümtaz Turhan'dır. Yakın zamanlarda Toplum ve Bilim dergisinin 2003'te yayımlanan 97. Sayılı ve Homo Academicus Alla Turca başlıklı özel dosyası da üniversite sorununu incelemektedir. Bu sayıda Hasan Ünal Nalbantoğlu’nun kaleme aldığı “Üniversite A.Ş.'de bir 'homo academicus': "Ersatz" yuppie akademisyen” başıılı makale bu bakımdan önemli değerlendirmeler içermektedir. Ali Menteş de Yeniversite başlıklı kitabında (2000) kurumsal ve teknik sorunların yanı sıra Türkiye'deki üniversitelerin bilgi-bilim anlayışı, üniversite kurumunun bireysel öğretim, araştırma gibi gerçek bilgi amaçlı fonksiyonlardan meslek edinimi fonksiyonuna evrilme süreci gibi zihniyete ilişkin sorunları da inceler.

6 İsmet Özel'in aşırı teorik ve sistemci düşünsel yaklaşımlara yönelik tenkidi için ayrıca bk. Özel (1999b, s. 213-248, 280-283). 
sal nitelikli, her şeyin pazar bağlantısı içinde anlam kazandığı, büyük oranda gayrişahsi davranış kalıpları üzerinden gerçekleşen ve kendisinin medenileşme olarak gördüğü söz konusu davranış kalıplarının kurumlaşmasının bir neticesi olarak kurumların insan üzerindeki belirleyiciliklerinin mutlaklaşmasını eleştirmektedir (Özel, 1999a, s. 77-78). Dolayısıyla İsmet Özel'in sıklıkla eleştirdiği en temel husus aşııı kurumsallaşma neticesinde ortaya çıkan bilimin gayrişahsi yapısıdır. Bu yapıda nesnellik adına bilginin kişiselliği hor görülür (Özel, 2000a, s. 287-288). İsmet Özel'e göre ise düşünceyi bütünüyle teorik kılarak onu akademik çalışmalar bağlamında almak, onu mümkün olduğunca kurumsallaştırıp nesnelleştirmek bir düşünceyi öldürmenin etkili yollarından biridir. Bu durumda o, modern teknolojik medeniyetin kendine rakip düşünceleri doğrudan karalamadığına, onları önce üniversite ve bilimsel kurum kafesine sokarak sonra da müze ve sergilere yerleştirerek yaşayan insanların elinde hayata biçim verebilecek bir düşünme tarzı olmasına engel olduğunu söyler. Ona göre yaşayan düşünce doğrudan pratik sonuçlara yönelmiş, insanların şimdilerini ve geleceklerini düzenlemede fonksiyon icra eden düşüncedir. Yaşayan bir düşüncenin hayatiyeti kurumlara, güçlü organizasyonlara, yasalarla korunmaya bağlı değildir. Düşünce bütün gücünü insanların mevcudiyetlerinin bir parçası hâline gelmesinden ve düşünce olmadığı takdirde kendileri de olmayacak olan müşahhas insanlardan alır (Özel, 2000a, s. 220-221). İsmet Özel, bir kişiyle irtibatı olmayan düşüncenin bir toplumla hiç irtibatının olmayacağını düşünür (Özel, 1999b, s. 204-206) ve "Bilgi bizim olsun, bize bitişik olsun istiyorum..." der (Özel, 1999a, s. 301). Bütün bu vurgularda İsmet Özel'in kurum ve kuruluş merkezli değil, insan tekleri ve fertleri bağlamında düşündüğü görülür (Özel, 1999a, s. 51; Özel, 2000a, s. 30). İsmet Özel'in kurum, sistem, teori karşısında ferdi, insan teklerini öne çıkarması aslında biraz da onun mekanizma-organizma arasındaki ilişki noktasında takındığı tavırla izah edilebilir durumdadır. İsmet Özel düşünen insan tekinin ve onun ait olduğu toplumun, idrak, anlama ve hareketleriyle oluşa katılma yönlerinin mekanik ve katı sistemci bir şekilde değil ancak canlı bir bünyenin sahip olduğu organik bir ilişkiler ağı bağlamında anlaşılabileceğini düşünmektedir (Özel, 1999b, s. 114-120). Bu vurgular, İsmet Özel'in insanın sistemli bilme faaliyetine bütünüyle karşıt olduğu anlamına gelmez. Zira o, modern bilimin kilise karşısında ilk çıktığı şartlarda gerçek bir bilme merakı olarak doğduğunu fakat teknokratik, bürokratik, elitist bir medeniyetin yapı taşlarını birbirine bağlantılı kılan bir harç durumuna dönüşmesiyle muhafazakârlaştığını, baştaki hayranlıkla kâinatı, evreni inceleme, gözleme olmaktan çıktığını, belirleyici olanın bilimsel heyecan olmadığını söyler. Bu yeni hâliyle bilim mütevazi bir öğrenme yöntemi olmaktan çıkıp şöhreti ve otoritesiyle var olan, efsanesiyle yaşayan ve yöneten tutarlı bir felsefe, toplumsal bir gereklilik, gü çlü ve kendinden başkasına söz hakkı tanımayan, saldırgan, baskıcı, kendi inançları, kendisine hizmeti zorunlu gören rahipleri (mühendisler) ve bir cemaati olan çok genel geçer, standart, her taraf için aynı özellikleri olan, kendisine karşı çıkmak için bile kendi yöntemlerinin kullanılmasını icbar eden bir yapı hâline gelmiştir (Özel, 2000a, s. 282-287). Sınırlı bir zaman dilimi içinde belirli bir malumatın çok sayıda insana aktarılması esasına dayanan bir malumatfuruşluğun hâkim olduğu modern bilgi kurumlarının ürettikleri bilgi ve bilimle hâkim güçlerin oluşturduğu bilimsel-teknolojik yapının işlevselliği ve kalıcılığı da sürekli olarak tahkim edilmektedir (Özel, 2000a, s. 103-105, 222, 224). 
İsmet Özel'in teorilere ve kurumsal yapılara bakışı temelde bu şekilde olunca, en azından son üç asırdır Türkiye'de icra edilen eğitimin "hayırsızlığının" sebeplerinin sıklıkla zikredildiği gibi teknik ve maddi koşullarla ilgili eksiklikler olmadığına ilişkin görüşü de daha iyi anlaşıır olur. Ona göre "Biz dünyanın en iyi işleyen, en etkin eğitim kurumlarına sahip olsaydık; bilgi dağarcığına sahip olma bakımından dünyanın en güçlü hocaları bizde olsaydı; dünyadaki en yüklü ders müfredatını biz uygulasaydık; bizim eğitim alanlarımız zihnî kapasite bakımından dünyanın en parlak kişileri olsaydı eğitimimiz yine hayırsız olacaktır. Çünkü ona göre bütün bunların sebebi hayır demeyi öğrenemeyişimizdir." (Özel, 2000a, s. 189-190).

İsmet Özel'in kurumsal ve profesyonel nitelikli düşünsel etkinliğe yönelik eleştirel tutumu Savaş Bitti şiirindeki kimi vurgular üzerinden de takip edilebilir niteliktedir. Aklı yoranlar ile dinç akılılar arasındaki ayrımına ilk kısımda işaret edilen İsmet Özel'in dinç akıllılara yüklediği kimi vasıflar, şairin dilinde kurumsal düzlemde faaliyet gösteren akademisyen, uzman tipi insanların vasıfları olarak da yorumlanabilecek imalar taşır. Mesela dinç akıllı bu tiplerin kendilerinde olmadığı durumda rahat yüzü göremeyecekleri vasıfları arasında kişiliğin şişip kabarması, kendi kralığından dem vurma, pehlivanlık taslama, kendi mülkünden ve saltanatından, bilgice sahip olduklarından bahis açma gibi özellikler bulunur. Bu grubun esas itibarıyla hâkim güçlerin oluşturduğu bilimsel-teknolojik yapının işlevsellik ve kalıcılığını tahkim eder nitelikteki rolleri itibarıly İsmet Özel'in kimi zaman alaylı denebilecek eleştirilerine konu olduğu görülür.

"Beklenmiyor beşerin üzerine gökten bir dindirişin serpilmesi" mısraları ise kurumsal yönü baskın mevcut düşünsel ortamın gökle ve hakikatle irtibatının zayıflı̆̆ına işaret eder. Şairin bu ortama ilişkin bir tasviri de onun bir tarla mesabesinde olduğudur. Ne var ki bu tarla her birimizin bir şekilde itildiği ve kendisi bizden bir mesele ümit ederken bizim besmelesizce yöneldiğimiz bir tarladır. Besmelesizce girilen bu tarlanın üretimi olan matbuatta, her türlü yazınsal etkinlikte insanın asli maksadının gizlendiği ifade edilir. "İnsafına sığındığımız yetmez miydi işgüzar/kamusal ilaçlama işçisi güruhunun" mısraları ile de düşünce tarlası üzerinde düşünmeye çalışan ve düşünebilmeyi beceren ya da beceremeyen kimselerin besmelesizce girdikleri tarladan bereket elde edemeyip ilaçlama gibi kamusal tedbir ve yöntemlerle üretkenlik sağlamaya çalışmaları ifade edilir.

Şair, kendiliklerinden sıyrılmış ve vagonda, üstelik birinci mevkide bir yer edinmiş bu yetişmiş kimselerin kendi astlarını kendilerine borçlu bırakacak şekilde başka memleketlerde, Avrupa çapında adları olduğunu söyler. Şaire göre bu kimselerin icra ettikleri rol insanlık tarihinde ilk defa bu şekilde gerçekleşen bir ihaneti de temsil etmektedir. Zira bu kimseler kendilerine ilişkin tasviri başkalarına kaptırmayarak bizzat kendileri yapmaktadırlar. Şair bunu "tarihte ilk defa çocuk annesiyle babasına/Poz verdirtiyor onların/Kaptırmıyordu portre ressamlığını yadlara" diyerek ifade etmektedir. Bu noktada dikkat çeken önemli bir nokta anne-babalarının şahsında temsil edilen, kendilerine, ait oldukları bütüne özgü tasvirler sunan çocukların dünyaya gelmelerine vesile olan anne-babalarına neyi tavsiye edeceklerinin bir merak konusu olmasıdır. Bu ifadeler, çocukların dünyaya gelmelerine vesile olan anne-babanın aidiyet duyulan ve mensup olunan dünya görüşüne tekabül etmesi durumunda asli anlamını bulurlar. Bir başka deyişle, memleketin evladı kendini var kılan asli unsura ilişkin bir tasvir yapmakta ve bu tasviri de yabancılara kaptırmayarak kendileri, fakat yabancıların tarzıyla yapmakta, resmin nasıl çekileceğine ve nasıl gözükeceğine, resimde 
nasıl durulması gerektiğine karar vermektedirler. Şair "yola getirsem elime ne geçecek/ hayat sahici bilgiyi sömürgeye saklamış/diyenler arasından birini" diyerek burada kimi özelliklerini saydığı tiplerden ümidini kesmiş görünür. Sahici bilginin sadece sömürgede mümkün görülmesi ise düşüncenin yabancı kaynaklarına yönelik aşırı yönelime işaret eder. Şairin hedef aldığı bu kitlenin bir diğer özelliği de "kokuşmuşa paha biçerek geçiniyor" olmalarıdır. Bu duruma "mülevves bir taksiratın çağlar boyu desteklenmesi" ifadeleri ile akademi ve uzmanlığın bir gereği olarak aslında çok da değerli olmayabilen bazı fikirlerin tekrarlanıp durmasına bir kere daha atıf yapılır.

Şairin okuryazar kesime yönelik şaşkınlığının bir diğer sebebi de onların her yerde bulunabilen, her şeyden kendisine malzeme çıkarabilen tavırlarıdır. Onlar bu uğurda gidecekleri yerin neresi olduğuna bakmaksızın savrulurlar. Şair bunu "ne arkadaşmış bunlar bir işin düşecek olsa/çat Beykoz'dadırlar çat Kumkapı'da/ha Beykoz'dadırlar ha Kumkapı'da" diyerek ifade eder. Şairin bu kimselerin her tarafta olabilen tavırlarından dolayı üzerinde durabilecekleri bir zemin tayin edemeyeceklerine olan vurgusu ve onlardan ayrıı̆ı̆ "uyar mıyım aklı vücuda merbut kılmayan bu takıma/tünemeye fırsat bulduklarında/ayırt edemeyeceklerdir hani halı hani kilim" dizelerinde bir kere daha ifade edilir. Burada altı çizilmesi gereken nokta, "aklı vücuda merbut kılmak" ifadesidir. Bu noktada şairin bunu yapamadıklarını düşündüğü kimselerin akıl ile vücut arasındaki irtibatı kopardıkları yorumunu yapabiliriz. Zira onlardan bir sınıf akla üst bir değer verirken diğeri ise akla ters istikamette olumsuz bir yer vererek tabir caizse bedene ve vücuda aşıı bir vurgu yapmaktadırlar. Şairin arayışında olduğu düşünce ise bu ikisi arasındaki irtibatı kurmuş olan düşüncedir. Bu vurgu aynı zamanda şairin gerçek bir bireysel ve toplumsal zeminde varlık kazanmamış ve dolayısıyla mevcutla irtibatı olmayan salt teorik düşüncelere yönelik yukarıda aktarılan eleştirilerine imada bulunur.

\section{Evrensellik ve Yerellik ya da "Burası" ve "Başka Yerler" Arasında Entelektüel}

Bu kısmın hemen başında öncelikle yerellik için aynı oranda düşünülemese de evrensellik kavramının düşünce söz konusu olduğunda ihtiyatlı bir şekilde kullanıldığına işaret edilmelidir. Zira bilgi ve düşüncede özü itibarıyla siyasi kavramlar olan küresellik ya da evrensellik değil tümellik ya da genel geçerlik söz konusudur (Fazlıoğlu, 2013).

Entelektüelin siyasi sorumluluğunu siyasi bir ihtiras olarak görüp eleştiren Benda bir millet, vatan gibi değerlere duyulan aidiyet ve mensubiyeti de millî ihtiraslar olarak değerlendirip eleştirir. Ona göre çağın insanları her zamankinden daha fazla bir şekilde ırksal, sınıfsal, millî ve siyasi ihtirasların peşine düşmüşlerdir (Benda, 2006, s. 11-36). Benda, aydının millî intirasların esiri olmasının örnekleri olarak kendi ülkelerini eleştiremeyişleri, eleştirdikleri takdirde de millete ihanet edenler kategorisinde değerlendirilmeleri, yabancı düşmanlığı gibi örnekleri zikreder (Benda, 2006, s. 44-47). Ona göre aydının vatanperverliği meselesinde yolu açan da Alman aydınlar olmuştur, milliyetçi aydın bir Alman icadıdır (Benda, 2006, s. 48-49). Vatanperverliğin özelliklerinden birisi, milletlerinden daha yüce bir gelişmenin varlığını yadsımak ve kendi düşünce biçimlerini millî bir düşünce biçimi ile ilişkilendirmek, bunu da diğer millî düşünce biçimlerine karşı öne sürme arzusudur (Benda, 2006, s. 50-51, 53). Benda'nın ihanet içinde olduklarını iddia ettiği aydınların bir vasfı da tikele bağlıı̆̆ı övüp evrenselliği, evrensel hakikat ve ahlakı yermeleridir. Buna bağlı olarak aydınlar milletleri başkalarıyla ortak olabildikleri özelliklerden ziyade başkalarından ayıran şiir, efsane 
gibi ürünlerinin bilincinde olmaya itmişlerdir (Benda, 2006, s. 64, 67, 79, 80). Benda birey ve bireysel olanın değerinin yüceltilmesini Alman düşünürlerle irtibatlandırırken buna karşılık evrensel olana duyulan metafizik merakın eski Yunan'ın insanlığa bir armağanı olduğunu ifade eder. $\mathrm{O}$ ayrıca tikele ve bireye vurgu yapan aydınların, Platon'dan Kant'a kadar olan varoluşu değişimin ötesinde kavrayarak kutsallaştıran düşünce biçiminin çöküşünü ilan ettiklerini ifade eder (Benda, 2006, s. 81-82). Zira bu durumda akla dayalı haklara karşı, gelenek, tarih ve geçmişten kaynaklanan hakların olumlanması söz konusudur (Benda, 2006, s. 94). Benda, bu noktada kendilerinin evrensel olduğunu, evrenseli yansıttığını iddia eden partikülarizmleri de dikkate almaz (Benda, 2006, s. 83). Benda'nın tikel, pratik ve yerel olana yönelik vurguları sıklıkla Alman düşünürlerle irtibatlandırmasında kendisinin Fransız olmasının da etkisi vardır. Benda'da bir kusur olarak gözüken bir diğer şey, özellikle nesnel, evrensel olduğu iddiası taşıyan belirli bir bilme tarzına yönelik eleştirilere cevap verirken meseleyi bazen salt bilimin ve bilim adamının savunusuna indirgemesi, hakiki entelektüel ile sıradan bilimciyi birbirinden net bir şekilde ayıramamasıdır. Bunun neticesinde de bilgi ve bilime yönelik her türden eleştiri, eylemin değerinin yüceltilmesine mukabil bilginin, bilimin değerinin alçaltılması, insanın düşünen yönünden ziyade etkin, istek ve arzu duyan yönüne vurgu yapılması olarak görülür. Benda'nın bu noktalarda safi düşüncenin yüceltildiğini söylediği eski Yunan'a ve özellikle de Platon'a gitmesi dikkat çeker (Benda, 2006, s. 119-121). Netice itibarıyla yazının başında yaptığımız evrensel, sınırları aşan aydın, akademisyen ve entelektüel tipi ile yerel, millî aydın, akademisyen ve entelektüel tipi arasındaki ayrım Julien Benda özelinde bir kez daha kendini göstermiş olur. Benda, işlevleri milletlerin gerçekçiliğine karşı çıkmak olan aydınların, tüm güçleriyle milletleri galeyana getirme konusunda kesin bir kararlıık sergileyerek yarım yüz yıldır böyle bir tutum benimsediklerini ve bu yüzden de onların bu tutumunu "aydınların ihaneti" olarak adlandırmaktan çekinmediğini ifade eder (Benda, 2006, s. 127). Fakat Benda'nın evrensel vurgusu ağır basan ve 1927 tarihli entelektüel tasvirinin de sadece Avrupalı olanları dikkate aldığı gözden kaçmamalıdır (Said, 1995, s. 39). Bu durumda Benda'nın entelektüel anlatısında her şey gibi evrenselliği de o zamanki Avrupa'dan ibaret gören bir tutumun daha baskın olduğu söylenebilir.

Heidegger'in, 1933 tarihinde yaptığı ve Nazizm ile ilişkisi noktasında çokça tartışma doğuran, Alman Üniversitesinin Kendini Beyanı başlıklı rektörlük konuşması ise gerçek bilim, düşünce ve felsefenin fayda ve uygulamaya dönük neticelerden bağımsızlığı ile ulusal amaçlar için bir araç hâline getirilmesi arasındaki çift kutuplu ilişkiyi dengeleme çabalarından birisi olarak gözükür. Heidegger, üniversitenin özerkliğinin bilim ile Alman yazgısının öze yönelik iradede aynı zamanda iktidara gelmesiyle sağlanacağını düşünür. Alman üniversitesinin öze yönelik iradesi ise Alman halkının tarihsel manevi vazifesine yönelik iradedir (Heidegger, 2002, s. 41). Dolayısıyla bilim diye bir şey var olmaya devam edecekse bile bu öncelikle Almanlar için bir şey olacaktır, bilimin kendi başına devam etmesi ya da nihayete ermesi bizatihi önemli bir şey değildir (Heidegger, 2002, s. 41-42). Heidegger Alman üniversitesinin manevi-tarihsel başlangıç noktası olarak ise Grek felsefesinin başlangıcını alır (Heidegger, 2002, s. 42).

Hem kendine özgü bir entelektüel tanımı ve çerçevesi geliştiren hem de entelektüelin siyasi işlevi bağlamındaki atıfların önemli mercilerinden birisi olarak Foucault da evrensel hakikatler uğruna kitlelere öncülük eden entelektüel rolünü reddeder (Keskin, 2000, s. 12). Yine de Foucault'nun entelektüel tanımının evrensel olanı bütünüyle dışladığı söylenemez. 
Zira ona göre iktidarlara karşı olarak kitlelerin elinden tutup onlarla siyasal bir mücadeleye girişecek entelektüelin sahip olduğu şey evrensel hakikattir (Keskin, 2000, s. 14-15). Fakat Foucault'nun Nietzsche'nin aydınlanma aklına yönelik eleştirilerinden hareketle büyük oranda keşfedilen evrensel hakikate bir eleştiri yönelttiği akıldan çıkmamalıdır (Keskin, 2000 , s. $18-21)$.

Entelektüelin kendi dili, geleneği, tarihi ve milliyeti ile ilişkisinin ne olacağı, ne oranda bunların kölesi ne oranda düşmanı olacağı meselesi Edward Said için de çözüme kavuşturulması gereken bir meseledir. Ona göre evrensellik, yetiştiğimiz ortamın, dilin, milliyetin sağladığı ve çoğunlukla başkalarının gerçekliğini görmeye engel olan ucuz kesinliklerin ötesine geçebilme riskidir. Özellikle dış politika, toplumsal politika söz konusu olduğunda tek bir standart aramak ve buna uymak için çabalamaktır (Said, 1995, s. 13-14). Said, entelektüeli kuralsız ve tanrısız olarak görür (Said, 1995, s. 14). Buna göre Said'de entelektüelin kendisini karşı karşıya bulduğu ikilem, Edward Shils'in de ifade ettiği gibi ya galip ve yönetenlerin oluşturduğu hâkim normlara karşı olmak ya da uzlaştırıcı bir tavır takınarak kamusal hayatta düzen ve sürekliliği sağlamaya çalışmak olarak ifade edilir ve modern entelektüelin esas rolü olarak ilk seçenek tercih edilir. Çünkü ona göre bugün normlar büyük oranda millete bağlıdır, millet de her zaman zaferi ve otoriteyi, sorgulama ve yeniden incelemeyi değil sadakat ve itaati ister (Said, 1995, s. 48-49). Evrensele olan vurgusuna rağmen Said, şartların Benda'nın düşündüğü anlamda evrensel nitelikli bir entelektüellikten söz etmek için hayli değiştiğinden söz eder. Artık farklı coğrafya ve dillerde farklı entelektüeller vardır, onların da kendi farklı entelektüel dilleri ve geleneklerinin bulunmaktadır, bu da evrensel entelektüel kavramında bir miktar aşınmaya neden olmaktadır (Said, 1995, s. 40-41). Fakat ona göre bu aşınma entelektüel birey hakkında bazı fikirler geliştirmeye engel olacak bir boyutta değildir. Said öncelikle milliyet ve milliyetçilik meselesini değerlendirir. $O$, bütün dünyaya ait olup hiçbir geleneğe ait olmayan bir dilde yazan herhangi bir entelektüel olmadığına, hepsinin de kendi dillerinde yazmalarının çok tabii olduğuna işaret eder (Said, 1995, s. 41). Fakat Said, George Orwell'ın klişelerin, aşınmış metaforların, bayat kullanımların dilin çürümesinin örnekleri olduğunu söyleyen ifadelerinden hareketle dilin de değişim dönüşüm geçirdiğini ve hatta siyasal dilin manipülasyon aracı olarak kullanıldığını söyler (Said, 1995, s. 41-43). Said, entelektüelin normal hâliyle tabii olan dinî, millî aidiyetini dengelemesinin bir yolu olarak da Fanon'dan hareketle, entelektüelin kendi toplumu için söz konusu olan krizin hayati ve derin olduğu zamanlarda bile nihai amacın ne olduğuna ilişkin sorgulamayı terk etmemesini ifade eder. Said'in ifadeleriyle kolektif buyruklar ile saf tutma arasındaki etkileşim bağlamında entelektüel her zaman görünüşteki amacı, mesela sömürgecileri kovmayı önemsemekle birlikte onu aşmayı ve onlar gittikten sonra ne yapacaklarını da düşünmelidir. Said bu vazifeye, entelektüelin ait olduğu toplum bazında yaşanılan sıkıntıları, bir milletin ıstırabını; eserleriyle estetik seviyede de evrenselleştirmek ve onu genel insani düzlemde de ifade edebilmek şeklindeki görevi de ekler. Bu tarihsel özgüllüğün kaybı anlamına da gelmeyecektir (Said, 1995, s. 52-55). Bir başka deyişle, inşasında öznel süreçlerin kendisinin spesifik konumu gibi unsurlar belirleyici olduğu entelektüel, tam bir şekilde ait olduğu bütünden yalıtılamasa da ait olduğu içerinin nabzını tutabilecek kadar dışarıdan, belirli bir mesafeden bakabilmelidir. Aidiyetinin aleyhinde olmasa da hem kendi konumuna hem de kendisinin olduğu yere ilişkin hakiki bir sorgulama için durduğu yeri "karşısına" alabilmelidir (Çağan, 2005b, s. 158). 
Evrensellik adına entelektüelin bir millete ya da herhangi bir bütüne aidiyet ve mensubiyeti eleştirilir fakat bu sefer de özellikle çağdaş dönemde entelektüelin kendisini içinde bulunduğu bağlantılar ve ilişkiler ağındaki bireyselliği başka bir sorun olarak ortaya çıkar. Said, 19. yüzyılda entelektüelin bireysel kimliği ön plandayken, 20. yüzyılda "fikirleri karşılığı para alan yöneticiler, profesörler, gazeteciler, bilgisayar ya da hükûmet uzmanları, lobiciler, allameler, sendikalı köşe yazarları, danışmanlar adı verilen genel bir gruba ait insanların sayısındaki artışla birlikte" bağımsız bir entelektüel bireyin var olup olamadığı sorusunun ortaya çıktığını söyler (Said, 1995, s. 76).

Üniversite meselesini Türkiye özelinde inceleyen Topçu'ya göre de bir üniversiteyi kuracak olan bir milletteki ilk iradeyi temsil eden felsefedir (Topçu, 1998a, s. 57-58). Topçu daha o zamandan sıra ile Fransız, Alman, İngiliz kültür ve maarifine teslim olduktan sonra büyük oranda fikir ve irfan ile değil siyaset ve sermaye ile Türkiye'ye dâhil olmuş teknik ve ticaret ağırlıklı Amerikan maarifine sığınmayı bir cinayet olarak görür. Ona göre bu eğitim tarzı millî hayat sahalarını çürütmekte, ruh ve ahlak temellerimizi derinden sarsmakta, memleketi kör ve sağır makinenin vatanı yapma azmini taşımaktadır (Topçu, 1998b, s. 27-28, 83).

Batı Avrupa zihniyetinde medeniyet, özellikle Sanayi Devrimi sonrasında hâkim olmak ve bu hâkimiyeti sürdürülebilir kılmak ideolojisine dönüşmüş ve özündeki amacı tahakküm etmek olan bu anlayış bu dönüşümü hem entelektüel hem de hayati alanda talep etmiştir. Bu dönüştürme de eğitim-öğretim ve üretim-tüketim gibi yollarla sağlanmaya çalışılan çağdaşlaşma şemsiyesi altında yapılır. Evrenselliğin de zaman zaman tıpkı çağdaşlaşma gibi bu türden genel geçer bir itham unsuru olarak kullanıldığını söyleyebiliriz. Oysa farklı medeniyetlerin ve hatta farklı kültürlerin dahi farklı teo-ontolojileri olduğu, zira onların dünya görüşü ve tasavvuru açısından da farklılaşmaları gibi bir durum söz konusudur (Fazlıoğlu, 2006). Buna bağlı olarak da düşüncenin yeri, yurdu, mekânı, vasatı ile muhtevası arasında güçlü bir ilişki vardır (Fazlıŏlu, 2008). ${ }^{7}$ Nitekim Türkiye söz konusu olduğunda ortak bir maşeri vicdan etrafında toplanamayışın nedeni, milletin maşeri vicdanından kopan ve her biri de "müphem bir iradenin biçimlediği, tayin ettiği birer cephe komutanı" mesabesinde olan aydınlardır. Zira Türkiye'deki aydının bir millete mensubiyet durumu söz konusu değildir. Bu anlamda küresel, evrensel düşünmek geniş düşünmek değil yersiz düşünmek olacaktır. Bunun karşıı̆ı̆ ise bir yerden hareketle düşünmektir. Nasıl ki merkezi olmayan bir daire tanımlanamıyorsa, merkezi olmayan bir düşünce de söz konusu değildir (Fazlıoğlu, 2013). ${ }^{8}$

7 Modern Batı düşüncesinin özellikle aydınlanma ile birlikte fazlaca vurguladığı rasyonellik, ilerleme, gelişmişlik vb. kendine özgü anlamları olan değerlerin evrensel oldukları fikri üzerinden geliştirdiği dile yönelik bir eleştiri ve düşüncenin Doğulu-Batılı biçimlerinin olup olamayacağına ilişkin bir sorgulama için bk. Murat (2005, s. 261-269).

8 Aydınların bu durumuna ilişkin bir örnek olarak bk. Demiralp (2002, s. 131). Yazar burada Mahmut Makal'ın Bizim Köy başlıklı kitabı ile ilgili olarak şunları söyler: "Anıt niteliğinde gördüğüm bu yapıtta köyün öğretmeni bir gün köylülerin önünde dili işlek sözde bir din adamı ile karşı karşıya gelir. Tartışmada köylülerin “Atatürk devrimlerinin öncüsü olan" öğretmene değil gerici sözde din adamına inanmayı yeğlediklerini görür. Şöyle der: “... tek adam bu kadar kuvvet karşısında ne yapabilir? Zaten en büyük düşüncem buydu: Nasıl savaşmalı bu kara kuvvetle? Hangi dilden anlar? Düşünüyordum ama bir çıkar yol bulamıyordum. Kendi kendimi yiyordum sadece." Türkiye'de hâlâ bu "kara kuvvet"e karşı savaşmak gerekmektedir. Bu savaşı kazanmanın birinci koşulu devletin aydın olmasıdır... Atatürk'ün kurduğu Cumhuriyet'te devlet aydın olmak zorundadır. Hangi Türk vatandaşı bu kara kuvvete, Jacques le Goff'un Orta Çağ'da aklı öldürmeye çalışanlar için kullandığı deyimle "kutsal cahilliğe" karşı savaşıyorsa o aydındır. Aydınlık, modern Türk devleti ve top- 
Ayrıca bu meseleye ilişkin tartışma, düşüncenin malzemesinin, nesnesinin dışarıdan/yabancı ya da içeriden/yerli olmasına indirgenebilecek bir tartışma değildir (Fazlığlu, 2008).

İsmet Özel, evrensellik meselesi bağlamında Batı'da tartışılan meselelerin denetim altında tutulan ülkelere olduğu gibi aktarılıp aktarılmadığı meselesini inceler ve dünyanın başka taraflarında meseleye nasıl bakılıyorsa Türkiye'de de öyle bakılmak gerektiği gibi bir duruma gelindiğini söyleyerek bunu eleştirir (Özel, 1999a, s. 50). O, her tarafta aynı standart kalıplarla hareket eden ve farklılıkları hep aynı ölçülere kıyasla değerlendiren, farklıııkları ortadan kaldıran, milletler üstü bir değer hâline gelmiş bir şey olan bilimi eleştirir. Zira bu durumda bilimin bulguları ve sonuçları değişebiliyor fakat onun evrensel, değişmeyen doğruları bulduğu ve bulacağı noktasındaki kesin inanç değişmiyordur (Özel, 2000a, s. 288-291). İsmet Özel'e göre evrensellik meselesine yapılan yoğun vurgu Türkiye'deki aydının kendisini işgalci, halkını ise doğru çizgiye getirilmesi gereken bir sömürge ahalisi gibi görmesine neden olmaktadır (Özel, 1999a, s. 54). Türkiye'de okumuşların halkla olan kopukluklarının sebeplerinden birisi de geniş kalabalıklarla ortak bir dil kurma imkânı veren İslamiyet'i ciddiye almamaları, onun avantajından faydalanamamalarıdır (Özel, 1999a, s. 253-254). Tabir caizse evrensele doğru açılırken ait ve mensup oldukları toplumun değerlerinin ıskalanması söz konusudur. İsmet Özel'e göre Türk aydını denilen acayip yaratık kendi ülkesinde yaşayan değerleri görmezlikten gelmekle kalmaz, uygun bulduğu bir başka kültürün unsurlarını da kendi öz malı sayar. Türk aydını hep kendi ülkesi dışındaki şeylere özenip kendisinin olana itibar etmez, somut aidiyet ve mensubiyetlerini hor görüp zihinlerinde yaşattıkları soyut bir ideal ölçeğinde düşünür (Özel, 2000a, s. 186-190, 212-213). Mevcut eğitim sisteminin düşünme biçiminde öğrenim görmeleri sebebiyle, Doğu ya da Batılı zihniyete mensup olmak gibi siyasal ideolojilerinin dışında aydınlar arasında başka bir ayrım yapılamaz. Zira her hâlükârda ortak oldukları nokta düşüncenin merkezî yeri ve yurdunu burada değil dışarıda aramalarıdır (Özel, 2000a, s. 222-223). İsmet Özel'de ise, belirli bir merkezden, yer ve yurttan hareketle düşünmenin, daha doğrusu muhtemel her türlü insani etkinliğin ancak bir merkezden hareketle icra edilmesi noktasında sahicilik kazanacağına ilişkin güçlü bir vurgu vardır (Özel, 2000b, s. 54-55, 64-65).

Fakat bu durum evrenselliğe ya da düşüncenin genel karakteristiklerine keskin bir karşıtlık şeklinde anlaşılmamalıdır. Zira İsmet Özel, düşüncenin genel geçerliliği ile özgünlüğü arasındaki ilişkiyi tartıştığı bir yazısında "Sadece kişilere ve kültürlere has, yalnız onların uhdesinde bulunabilecek düşünceler mi var; yoksa düşünce her kişide, her kültürde kendi geçerliliğini sağlayacak özellikteki bir insan yetisinin ürünü müdür?" sorusunu sorar. Ona göre bu görüşlerden yalnızca birinin doğru olduğu iddia edilemeyeceği gibi aksine ikisi de doğrudur. Çünkü düşüncenin diğer düşüncelerle arasındaki ilişki sadece ayrılığı yani özgünlüğü cihetinden olursa bu, o düşüncenin tanınamayacağı, onunla bir başkasının irtibat kuramayacağı anlamına gelir. Buna karşılık bir bireye veya bir kültüre özgü olmayan bir düşüncenin de aynı oranda farklı bir düşünce olarak nitelenebilme vasfının kaybolacağı ortadır (Özel, 1999b, s. 204-205). Dolayısıyla genel geçer düşüncelerle bireye veya kültüre, topluma özgü düşünceler arasında birbirlerinin genel/evrensel ya da tikel/yerel olma durumlarını ortaya çıkaracak

lumunun tanımında, doğasındadır. Dar bir grubun niteliği, ayrıcalığı olarak görülmemelidir..." Bu şekildeki aydın tutumuna başka bir örnek, H. Batuhan'ın entelektüel kavramı üzerine başılılı makalesinde de görülür (Batuhan, 2002, s. 98-100). Türkiye'deki aydınların bu tuhaf durumu için ayrıca bk. Şan (2005, s. 292-304). 
bir ortaklık vasatının olması gerekecektir. Zira ortaklık olmadan ayrışma gerçekleşmez. İsmet Özel aynı bağlamda farklılığın nerede ortaya çıkabildiği sorusuyla da ilgilenir. Buna göre bir düşüncenin diğer bir düşünceden farklılığı ilk olarak o düşüncenin insanda oluşmasına etki eden şartlar ve niyetler aracılığıyla olur. Buna ilaveten, düşüncesi ile özgün bir biçime kavuşmuş olan bir birey ya da kültür bir yapabilirlik alanı oluşturur. Dolayısıyla bir kişi ya da kültürü diğer kişi ya da kültürler karşısında cazip kılacak olan bu yapabilirlik yani eylem alanıdır. Başka kişi ya da kültürlere cazip gelmeyen ve dolayısıyla alınabilecek düşüncesi olmamak demek, söz konusu düşüncenin yapabilirlik imkânından mahrum olması ve başka kültürlerin yapabilirlik ve eylem alanlarına hapsolmuş bir şekilde varlığını devam ettirmesi anlamına gelir (Özel, 1999b, s. 205-206). ${ }^{9}$ Bu noktada İsmet Özel'in evrenselden anladığının İslam olduğuna da işaret edilmelidir (Özel, 1999a, s. 106). İsmet Özel'in evrensellik ve yerellik, aidiyet ve mensubiyet bağlamındaki vurguları Savaş Bitti şiirinde burası ile başka yerler arasında yaptığı ayıımda da gözükür. Başka yerler, yukarıda ifade edilen şairin düşüncesini harekete geçiren şeyin, düşünce sıkıntısının, eser ve etkilerinin kendi yurduna gelip kök salmasına neden olmasını istemediği yabancı diyarlardır. Nitekim şairin başkalığı kendilerine layık gördüğü yerler yenilebilecek şeylerin tek başlarına yenmesi durumunda mayhoş bir tatlarının olduğu yerlerdir. Bunun ardından şair düşüncenin kendisinde yol açtığı etkilerin sebebini aramaya koyulur. Şairi düşünce emeğine, düşünceyle boğuşmaya iten sebep ne olabilir? Bu sebeple ilgili bir ihtimal olarak La Belle Dame Sans Merci'nin Türk ilinde fütur eylemeksizin dolaşması ve hatta yerleşmesi zikredilir. Bu, İngiliz şair John Keats'in ünlü bir şiiridir. John Maynard Keynes'ten Nefretimin Yirmi Sebebi başııkı şiirinde de görüldüğü üzere, İsmet Özel'in hem şiirinde hem de nesrinde İngiliz ve İngiliz etkisi sürekli olumsuz bir imaj olarak yer alır. Dolayısıyla şair yabancı bir eserin, etkisinin kendi yurdunda fütursuzca dolaşmasının ve karar kılmasının, kendi sevgilisiyle, yani düşünceyle, düşünce çabasıyla olan sıkıntılı ilişkisinin sebebi olması durumunu ortadan kaldırmak ister.

\section{Entelektüel ve Eylem-Siyaset-Iktidar İlişsileri ya da Savaş Olarak Düşünce}

Bir bilim adamı ile entelektüeli ayıran şeyin, entelektüelin bildiği şey uğruna çeşitli zorluklara ve sıkıntılara hatta kimi zaman hayatı pahasına bildiğinden vazgeçmemeye tahammül etmesi olduğu söylenmiş ve entelektüeli entelektüel yapan asıl şeyin eylemselliği olduğu ifade edilmiştir (Arslan, 2002, s. 201-206). ${ }^{10}$ Eylemsellik bir taraftan entelektüelin bireysel sorum-

İsmet Özel'de düşüncenin yerine, yurduna, zaman ve mekân boyutuna ilişkin özellikleri ile ilgili olarak ayrıca bk. Özel (2000a, s. 31-38).

10 Chomsky de entelektüel teriminin zorunlu olarak entelektüel meslekler olarak görülen mesleklerde çalışan insanlarla ilişkili olmadığını, meslek itibarıyla bu sınıflara ait olmadığı hâlde entelektüel denebilecek kimseler olduğunu söyler (Chomsky, 2011, s. 8). Fakat bu bölümün başında hemen vurgulamamız gereken önemli bir nokta vardır: Bu kısımda entelektüelin eylemselliği, sorumluluğu içinde yaşadığı dünya ile eleştirel de olsa ilgisi gibi özelliklere dair tahliller günümüzde ilk anda akla elen anlamıyla aydınları, akademisyenleri ve entelektüelleri siyaset ve ekonomi gibi pratik piyasa koşullarında işlevsel kılmaya yönelik vurgular olarak düşünülmemelidir. Zira bu durum Frank Furedi'nin Nereye Gitti Bu Entelektüeller kitabında philistinizm kavramı üzerinden dile getirdiği oldukça keskin eleştirileri haklı çıkaran bir tutum olacaktır (Furedi, 2014, s. 13-15). Belki bu noktada akılda tutulması gereken şey entelektüelin eylemselliği ve savaşçılığı derken bunun mevcut piyasa koşullarında çabucak tedavüle sokulabilir ve kullanılabilir olmayan daha üst bir muhalefet diline, hak ve hakikat adına üst düzeyde bir eleştirellik mesafesini muhafaza etme tutumuna gönderme yaptığıdır. 
luluğuyla ilişkili iken daha geniş anlamda onun siyaset ve iktidar başta olmak üzere farklı kurumsal yapılar karşısındaki konumuyla da ilişkilidir. Le Goff'un yüklediği anlamıyla entelektüellerin en geniş anlamda eylemsellik diyebileceğimiz yönetim mekanizmalarıyla ilişkilerinin tarihi de oldukça geri gider. Fakat bir tür entelektüel teknokrasi denebilecek bu durum entelektüellik açısından bir parça tehlike de arzeder. Zira "Bilimin sonunda siyasete vardığı doğruysa da bilim adamının sonunda siyasetçi olması ancak nadiren iyidir." (Le Goff, 1994, s. 154-155; Çağan, 2005b, s. 171). Zaten genel anlamıyla entelektüel ve iktidar arasındaki ilişki doğası gereği geçimsiz, uyumsuz ve gerilimlidir. İktidar bir taraftan iktidarını pekiştirmek ve toplumu değiştirmek için entelektüele intiyaç duyar, öte yandan entelektüelin sorumsuz ve başına buyruk gibi gözüken eleştirelliğinden rahatsız olur (Çağan, 2005b, s. 162-170).

Modern anlamıyla aydın ve entelektüel tipinin eylemliliğine yönelik güçlü vurgulardan birini tabii olarak Gramsci'de buluruz. "Soyut ahlakçılığa olduğu kadar biçimsel öğreticiliğe, doktrinciliğe de karşı çıkmış bir savaş̧̧ı" olarak nitelenen Gramsci'ye göre bilim, günlük mücadeleleri küçümseyerek yüksekten bakan, gerçeklerden kaçan değil, insanın bütün benliğiyle, bütün yeteneği ve özgürlüğüyle kendini verdiği, yaşamını adadığı, siyasal kavgasının devamı olan bir şey olmalıdır (Gramsci, 2003, s. 11-12). O, yeni aydının özelliğinin söz ustalığında, duyguları ve tutkuları bir an için harekete getiren bir dış güçte aranmadığını, bu özelliğin aydının pratik hayatta yapıcı, örgütleyici ve sürekli inandırıcı olarak karışmasında olduğunu söyler. Aydın sadece bir söz ustası olmadığı gibi soyut kafanın da üstünde olup teknikten bilime ve hümanist tarih görüşüne yükselir. Bu yükselme olmaksızın o sadece uzman kalır ve uzmanlık ile politikacılığın bileşimi olan yönetici olamaz (Gramsci, 1983, s. 25).

Benda ise, insanların kendilerini yansız veya metafizik bir varoluş tarzından ziyade, gerçek veya pratik bir varoluş şekline göre konumlandırma arzusunda olduklarına, bunu da şimdiye kadar hiç olmadığı kadar bir bilgi ve bilinçlilikle yaptıklarına işaret ederek bunu eleştirir (Benda, 2006, s. 34, 83). Benda bunun ardından okumuş-yazmış ve eğitimli insanlar olarak ifade ettiği aydınlar sınıfına intikal eder ve onların siyasi ihtirasla ilişkilerini inceler. O, Leonardo da Vinci, Malebranche, Goethe, Erasmus ve Kant gibi aydınlardaki bu olumlu tutumun 19. yüzyıl sonu itibarıyla değiştiğini, aydınların siyasi ihtiras oyununa katıldıklarını düşünür. Benda, temel işlevi ebedî şeylerin arayışı olmasına rağmen yine de kendisini devlet meselelerine vererek daha da güçleneceğine inanmasının modern aydının bakışını yansıttığını belirtir. Bu durumda pazara düşen aydınlar sadece gerçekçi bir ihtirasın başarılı olmasına hizmet ettiğinde, aydın olarak işlevlerini yerine getirmede başarısız olurlar. Benda, pazara inmesinin akabinde eğitimsiz insanlar tarafından övülen aydının görevine ihanet ettiğini söyler (Benda, 2006, s. 38-43). Benda'nın aydın tanımı, Gramsci'nin işaret ettiği organik entelektüel tanımını incelerken gördüğümüz üzere piyasa ve sermaye tarafından kullanışlı entelektüel tipine karşıt olması ve yüksek bir entelektüel ideale işaret etmesi bakımından ilk başta olumlu gözükür. Fakat bu durum da bir miktar aşırıya doğru kaydığında bu sefer entelektüelin sorumluluğu meselesinde dışarıda kalma tehlikesi ortaya çıkacaktır. Bunun da nihai anlamda tıpkı piyasa entelektüeli gibi tam olarak vazifesini icra etmemekle malul olacağını söyleyebiliriz. Fakat Said, adalet ve hakkaniyetle Fransa'nın kimi uygulamalarına karşı çıkmış Fransız entelektüelleri olumlayarak zikretmesinden hareketle Benda'nın aslında tam olarak bunu kastetmediğini, Benda açısından entelektüellerin temel sorununun sahip oldukları ahlaki otoriteyi bağnazlık, kitle dalkavukluğu, milliyetçi çığırtkanlık, sınıf çıkarları gibi kolektif ihtiraslar için kullanmaları olduğunu söyler (Said, 
1995, s. 24). Said, Benda'nın entelektüelinin fildişi kulesine kapanıp konuşan bir kimse olmadığını, aksine entelektüelin gerçek bir metafizik tutkudan, adalet ve hakkaniyet ilkesinden hareketle yozlaşmayı eleştirdikleri, zayıfları savundukları ve baskıcı otoriteye meydan okudukları zaman tam anlamıyla entelektüel olacağını söyler. Entelektüel güçlü bir birey, statükoya karşı çıkan bir muhaliftir (Said, 1995, s. 21-24).

Heidegger de bu bağlamda Grek theoriasının salt kendi hatırına var olan bir şey olarak görüldüğü çağdaş yorumu reddeder. Ona göre teori kendi hatırına olmayacağı gibi bizatihi mevcut olan şeye yakın olarak ve o şey tarafından kuşatılarak oluşur. Fakat Grekler aynı zamanda bu theoriayı, insan energiasının, eylemesinin, etkinliğinin en yüce tarzı olarak da görmeye çalışmışlardır. Bunu yaparken de basitçe pratiği teoriyle uyumlu kılmayı değil, teoriyi sahih pratiğin yüce gerçekleşmesi olarak anlamayı tercih etmişlerdir. Dolayısıyla Heidegger'in yorumunda Greklerin bilime kültürel bir hazine olarak değil kendi halk ve devlet varlıklarının deruni belirleyici merkezi olarak baktıklarına işaret edilir. Bu anlamda bilim, sadece bilinçsiz olanı bilinçli kılmanın da aracı değildir (Heidegger, 2002, s. 43). Heidegger, bilim ve felsefi düşünce etkinliğini ruhun boş bir feraseti ve keyfî bir zekâ oyunu, sınırsız bir rasyonel analiz meşguliyeti olarak görmekten kaçınır. Buna benzer şekilde bir halkın manevi yapısı da o halkın kültürel bir üst yapısı, faydalı bilgi ve değerlere dair bir deposu değildir. Ona göre bilim de düşünce de hem bu zekâ oyununu ve sınırsız rasyonel analiz tutkusunu hem de bilgi ve değerlerin bir depoda muhafaza durumunu aşan ve halkın ait olduğu bütünün derinliklerinde ortaya çıkarak milleti harekete geçiren kuvvettir (Heidegger, 2002, s. 45-46).

Geliştirdiği yeni entelektüel tanım ve çerçevesi yine kendisinin iktidar analiziyle oldukça ilişkili olan Foucault da zamanındaki iki geleneksel iktidar tipini inceler ve ekonomi temelli iki modelin de özellikle Batı'da 17. yüzyıldan sonra ortaya çıkmış yeni, çoğul ve değişik ilişkiler ağının her bir tarafına sinmiş iktidar tiplerini açıklayamadığını söyler. Zira artık sabit bir iktidar olmayıp varlığını hareketlilik ve işleyişte bulan yeni iktidarlar vardır ve yapılması gereken bu yeni iktidarların işleyiş̧inin analizidir. Foucault aynı zamanda bu iktidar işleyişlerinin bir bilgi alanı oluşturduğunu da söyler ve "bilimsel söylem olarak bilginin taşıdığını iddia ettiği hakikat" ile iktidarın bu anlamda kesişerek birlikte bir iktidar rejimi oluşturduklarını ifade eder. Dolayısıyla yeni entelektüelin yapacağı siyasi mücadelenin muhatabı tek bir biçim hâlindeki iktidar değildir. Artık siyasi mücadele, tıpkı iktidar gibi çoğul ve yerel olmalıdır. O iktidar zincirinin tekil halkalarını, disiplinlerini, kurumlarını, pratiklerini, teknolojilerini ve onların arkasındaki bilgi/iktidarın hakikatlerini hedeflemelidir. Foucault bu noktada kendisinin ikili entelektüel tipiyle tekabül eder bir tarzda artık siyasi mücadeleyi yürütecek entelektüelin geleneksel ve evrensel entelektüel değil, spesifik ve uzman niteliğindeki entelektüel olduğunu ifade eder. Bu yeni entelektüel tipi yerleşik iktidar ilişkilerinin içinde kaybolup gitmek, yerleşik iktidar sisteminin sürekliliğine katkıda bulunmak ya da bu iktidar ilişkileriyle savaşarak onları değiştirmek gibi çift taraflı bir rolün önünde bulunur. Fakat mevcut durumda kitlelerin bilgi edinmek için entelektüellere ihtiyaçlarının olmadığı da ortaya çıkmıştır. Dolayısıyla artık entelektüele düşen vazife siyasal anlamda da global değil yerel bir nitelik arz eder. Ne var ki yerel bir mücadele hattında bir danışman ya da uzman olarak işlev gören bu entelektüel mücadele kadar manipülasyonun da aracı olabilir durumdadır (Keskin, 2000, s. 21-26). Fakat Foucault'nun siyasal anlamda entelektüele biçtiği rolün kitlelere yönelik ders verici nitelikteki bir tavsiye olmadığına da işaret edilmelidir (Foucault, 2000, s. 319-320). 
Edward Said, entelektüelle ilgili çoğu çalışmanın fazla bir şekilde entelektüelin tanımı sorunuyla ilgilendiği hâlde, onun imgesi, imzası, fiilî müdahalesi ve performansının yeterince değerlendirilmediğini düşünür. Hâlbuki bunlar gerçek bir entelektüelin yaşam suyudur (Said, 1995, s. 29). Said'e göre entelektüelin bir görevi, insan düşüncesini ve insanlar arası iletişimi kıskacı altına alan klişeleri ve indirgeyici kategorileri kırmaktır (Said, 1995, s. 11). Said'e göre entelektüeller mümkün olduğunca geniş halk kesimlerini muhatap alırlar. Fakat yine de entelektüelin meselesi kitle toplumuyla olmayıp kamuoyunu biçimlendiren, konformistleştiren, iktidardaki çokbilmişlere güvenmeye teşvik eden uzmanlar, eş dost grupları, profesyoneller ve düzen adamlarıyladır. Düzenin adamları belli çıkarları gözetirken entelektüeller şovenist milliyetçiliği, sınıf, ırk, toplumsal cinsiyet imtiyazlarını sorgularlar (Said, 1995, s. 13). Said'e göre entelektüelin asli görevi baskılar karşısında görece bağımsızlığını koruma arayışına girmektir. Bu yüzden de o sürgündür, marjinaldir, amatördür, iktidara karşı hakikati söylemeye çalışan bir dilin sahibidir (Said, 1995, s. 15). Said entelektüellikten birilerinin dümen suyuna gitmeyi değil muhalefete adanan ruhu anlar (Said, 1995, s. 16).

Said, Gramsci'nin işaret ettiği mevcut yeni ilişkiler ağında faaliyet gösteren organik entelektüeline ilişkin koşulları inkâr etmese de entelektüelin başka profesyonel alanların altında kaybolma tehlikesinden de söz eder ve entelektüelin "toplumda, kimliksiz bir profesyonel, salt kendi işine bakan bir sınıfın yetenekli bir üyesi olmaya indirgenemeyecek özgül bir kamusal role sahip bir birey olduğunda" ısrar eder (Said, 1995, s. 27, 2002, s. 37-57). Said'in entelektüeli, belirli bir kamu için belirli bir mesajı, görüşü, tavrı, felsefeyi temsil eden, kolay kolay hükûmetlerin ve büyük şirketlerin adamı yapılamayan, evrensel ilkeler temelinde devamlı unutulan, görmezlikten gelinen insanları, meseleleri temsil etmek için var olan, isimsiz bir memurla ya da ihtiyatlı bir bürokratla karıştııımaları mümkün olmayan bir tiptir (Said, 1995, s. 28-29). Said daha sonra sürgünlüğü yüzünden uyum gösteremeyen, bunun yerine çoğunluğun dışında kalan, iktidarda yer edinmeyen, onunla iş birliği yapmayıp direnen entelektüel ile yeni ve palazlanmakta olan egemen iktidar yapısı içinde yerini alan entelektüel arasında mukayese yapar (Said, 1995, s. 62-72). ${ }^{11}$

Topçu'nun üniversitenin üç fonksiyonundan bahsettiğine ve bunlardan üçüncüsünün devletin realist yönü ile idealist yönü arasındaki ilişkiyle açıklandığına işaret edilmişti. Bu yön, Topçu'nun zihninde üniversitenin ve dolayısıyla bir memleket münevverinin siyaset ve politikayla ilişkisinin nasıl olacağına ilişkin olarak da yorumlanabilir niteliktedir. Buna göre, devletin realizmi devlet refleksleriyle, koruma ve disiplin güdüsüyle, inzibat ve idare vazifeleriyle ilişkilidir. Fakat devlet realizminin bu yönü şuur, terakki ve inkişaf ile ilgili yönleri garanti etmez. Üniversitenin devlet idealizminin, terakki ve inkişafının muharrik gücü olan şuuru ise dogmatik vasıtalarla iş gören devlet adamlarının karşısına, anlayış zihniyetine sahip mütefekkirlerin çıkmasını temin eder. Siyaset ve idare adamları direktiflerini bu mütefekkirlerden almak zorundadırlar. Devletin siyasetine de hâkimiyeti altındaki milletin tarihi hakikatleriyle felsefi düşünüşü yön vermelidir (Topçu, 1998a, s. 59-62). Bir başka deyişle aydın ve entelektüeller iktidar ve siyasete muhtaç değil iktidar ve siyaset, daha da genelinde devlet, aydın ve entelektüellere muhtaçtır. Bu anlamda Topçu, üniversitenin politika ve siyasi entrikalarla iç içe olmasını da olumsuz bulur (Topçu, 1998b, s. 90, 147). 
İsmet Özel ise, her şeyden önce Batı'nın sahip olduğu düşünce seviyesinin ehliyet ve salahiyetine sahip olmak isteniyorsa bunun artık bir düşünsel mesele olmaktan çıktığını ve bunun siyasi bir mesele yani "ret" veya "kabul" meselesine dönüştüğünü söyler (Özel, 1999a, s. 33). Dolayısıyla İsmet Özel'in kendisini karşısında konumlandırdığı, felsefi tezlerine İslami bir görüşten hareketle karşı çıktığı temel düşünce, İbrani-Hristiyan medeniyeti diyerek atıf yaptığı ve kasvet niteliğini öne çıkardığı modern Batı düşüncesidir. Buna karşılık İslam ise İsmet Özel düşüncesinde mevcut durumdan çıkış için ileri sürülen bütün ideolojilerin ötesinde yegâne güvenlik hattı olarak yer alır (Özel, 1999b, s. 334-335). İsmet Özel özellikle Descartes, Kant ve Hegel gibi isimlerin ana noktalarını teşkil ettiği modern Batı düşüncesini bir muhatap olarak alır ve eleştiriler yapar. Bu eleştiriler geniş bir felsefi meseleler bağlamında çeşitlilik gösterir.12 İsmet Özel bu iki düşünce tarzı arasındaki karşıtlığı ve buna bağlı olarak yapılması gereken tercihi "deli bilgiçlerin medeniyetiyle bilgin savaşçıların barbarlığı arasında bir seçim" olarak görür (Özel, 1999b, s. 203). Fakat bu karşıtlık İsmet Özel'in kendisine yöneltilen bir eleştiriye verdiği cevapta da görüldüğü üzere, toptan bir ret ve hiç dikkate almama anlamında, Batı düşüncesinin temsilci isimlerinin detaydaki görüşleri bilinmeksizin takınılan bir tavır değildir. Modern Batı düşüncesi İsmet Özel için ortaya çıkardığı ve bugün bütün insanlığı ilgilendiren sorunlar hâline gelmiş temel problemleri itibarılla muhatap olunması, eleştirisinin yapılması ve aşılması gereken bir düşünceye işaret eder. Ayrıca o, kendisinin Batı düşüncesi ile ilişkisinde gözüken türden tereddüt ve gidip gelmeleri itiraf ederek bunun toplum olarak bir aydınlanmaya olan ihtiyacımızın belirtisi olduğunu ifade eder (Özel, 1999a, s. 287-288).

İsmet Özel'de düşüncenin, durduğu yer belli insan teklerince yürütülen bir savaş olarak görülmesi bağlamında önemli olan bir diğer husus onun kendisini okuryazar kesimde olduğunu söylediği ve edebî numaralar olarak gördüğü iki özellikten de uzak tutma gayretinde ortaya çıkar. Bu iki özellikten birisi genel geçer yargılara prim verilerek genelin hoşnutluğunu kazanacak tarzda yazıp çizmek diğeri ise yazarın kendisini perdeleyerek okuyucunun karşısına çıkmasıdır (Özel, 1999a, s. 68). İsmet Özel Türkiye'de sağda ya da solda eli kalem tutan insanlar arasında bir al gülüm ver gülüm politikası olduğunu ve kendisinin bu politikaya dudak bükerek herkesin yerini bilmesi gerektiğini söylediğini ifade eder (Özel, 1999a, s. 91). İsmet Özel'de taraf olmak, tarafını belli etmek önemli bir husus olarak gözükür (Özel, 1999a, s. 131-132). Zira bütün çağlar gibi belalı olan çağımızda bu belalara karşı bir savaşı ancak insan kalarak yürütmek mümkündür (Özel, 1999b, s. 342).

İsmet Özel Savaş Bitti şiirinde ise "onlara eziyet altında/tecrübemin bana öğrettiğini/söyledim açık seçik anlamadılar/avama sebil için açık saçık söylediysem de nafile/benim sırrım nefsimi ıslah etmeyişimde saklı/beni yazın keten pantolonlu kışın kalın kazaklı/görmeseler ayağa düştüğümün resmiydi çoktan..." mısralarıyla aydın ve entelektüelin ahlaki boyutuna vurgu yapar ve onların asıl kimliğine dâhil olması gereken bir şey olarak ahlak ve nefsin ıslahı meselesine işaret eder. Dolayısıyla hakiki anlamdaki aydın ve entelektüel tipinin savaşının öncelikli muhatabı kendi nefsi olmalıdır.

İsmet Özel'de yıkmak daha baştan önemi ifade edilmiş bir şey olarak gözükür: "yıkmak demiştim on dokuz yaşımdayken/kutsal kinidir yürekli olmanın/aradan kaç yıl geçtiği

12 Bununla ilgili olarak bk Özel (1999b, s. 110-114, 114-120, 189-191, 201-203, 213-248, 332-333, 2000a, s. 5053, 136-140, 150-153). 
hesaplanabilir/beni çatık kaşla yaşlandıran/diktatörlük bu işte..." Entelektüelin faaliyeti, eleştirici, sorgulayıcı, sarsıcı, yerinden edici gözükse de bir şey yıkııırken yerine yenisi konulur bir nitelik gösterir. Entelektüelin şahsında yıkma ve yeniden üretim dengelenir (Çağan, 2005b, s. 160). İsmet Özel, düşüncenin bir savaş durumu olduğuna "çatışmalar cephede/ savaş arkalardadır" mısralarıyla da imada bulunur. Bu durumda cephede çatışmanın kazanılıp arkada savaşın kaybedilmesi durumu mümkündür. Zira "bundan böyle inkârcıları küçültmenin/büyük bir engeli var" mısraı cephedeki bir kazançtan sonra geride düşünsel planda savaşı kaybetmiş olmaya işaret eder niteliktedir.

Şairin akıl ile vücut arasındaki irtibata dair yaptığı önemli bir vurgu bu sefer kuru bilginin eleştirisi ve eylemselliğin önemsenmesi gibi de okuyabileceğimiz bir bağlamda gündeme getirilir: "...yemek buldun mu ye dayak buldun mu kaç/biyos derlerse hayat logos derlerse akıl/bunları sular seller gibi bilmeyi marifet sanma sakın/marifet aklın ne kadarı hayatın dâhilinde/bunu bilmek/yahut keşfetmek hayatın/hangi kısmı dolduruş ne kadarı akıldır..." Burada ifade etmeye çalışılan ilk şey aslında ilk üç mısrada gizlidir. Buna göre biyosun hayat, logosun akıl olduğu türünden malumat bir önceki mısrada ifade edilen yemek bulunduğunda yenilmesi dayak bulunduğunda kaçılması tavsiyesi kadar sıradan bir bilgidir. Dolayısıyla ikincisine dair bilgi, belki malumat olabilse de doğrudan bir marifet olamaz. Oysa yazarın ulaşma arzusunda olduğu marifet, sonrasında ifade edildiği üzere başka bir şekilde, yani akıı hayata dâhil edilmesi veya hayatın ne kadarının dolduruş ne kadarının akıl olduğunun keşfedilmesi durumunda gerçekleşir. Şairin burada ifade etmeye çalıştığı şey açıktır: Düşünce, entelektüel bir gevezelik olmamalıdır. Bu entelektüel gevezelik tek başına akla (logos) ya da tek başına hayata (biyos) yönelik olabilir. Sahih bir düşünce biraz yukarıda da ifade edildiği üzere akıl ile vücut, akıl ile hayat arasındaki irtibatı sağlamış olan düşüncedir. ${ }^{13}$

\section{Sonuç yerine: Savaş Bitti mi?}

Yakın zamanlarda yayımlanmış olan yükseköğrenim yol haritasında üniversite sisteminin tarihsel olarak geçirdiği aşamaların nihai noktası, globalleşen ve küreselleşen dünyada gitgide daha fazla şirket mantığıyla işleyen Amerikan tarzı üniversite olarak ifade edilmiş ve çağdaş üniversitenin Amerikanlaşmak ile başka bir alternatif arasında tercih yapmakla karşı karşıya olduğuna işaret edilmiştir (Çetinsaya, 2014, s. 33). Bu şekildeki bir netice, üniversiteyi hakikati ve bir milleti taşıyacak ana damar olma vasfından kopartarak onu siyaset-sermayeticaret ve eğitim-öğretim sarmalının istihdam aracı ve alanı hâline getirecektir. Buna ilaveten üniversitelerin ve akademisyenlerin toplumsal ve siyasal rolleri gibi tanımlamalarla her biri de birer şirket mantığı ile çalışan üniversitelere mensup, sermaye ve siyaset için çeşitli işlevler icra eden bir entelektüellik kastediliyorsa bu olsa olsa Furedi'nin keskin bir dille eleştirdiği ve Gramsci'nin organik entelektüellerine karşılık gelen bir tip olacaktır.

Bu yazıda farklı isimler üzerinden yapılan incelemenin, özellikle modern bilim söz konusu olduğundaki aynı toparlayıc birlik idealinin bizim de idealimiz olmasına yönelik olmadığına işaret edilmelidir. Burada daha ziyade benzer bir dağınıklıkla malul bilim ve felsefe yapma tarzımızın müşterek bir ideal etrafında nasıl yeniden örgütlenebileceğine ilişkin 
bazı örneklere işaret etmek amaçlanmıştır. Görüldüğü üzere burada incelenen örnek isimlerden her biri kendi zaviyesince bir aydın ve entelektüel tanımlaması yapmışlardır. Birisi için entelektüel millî olanı dışlamayan bilakis bizzat oradan hareketle neşvünema bulan bir tip iken (Heidegger), bir başkası bunu bir ihtiras olarak görmüştür (Benda). Yine Benda aydın ve entelektüele bu dünya ile ilgisi sınırlı asıl derdi yüksek bilim, sanat veya metafizik olan bir kimlik verip mistik bir karaktere büründürürken Edward Said ve Gramsci gibileri ise entelektüeli bu dünyanın meseleleriyle doğrudan irtibatlı, o meseleler karşısında taraf ya da muhalif olabilen bir kimse olarak görmüşlerdir. Fakat kimi zaman bir yönleri ağır bassa da aydın ve entelektüeli ya da bilimsel ve felsefi faaliyeti bir miktar bizzat bilim ve felsefe bir miktar da bir milletin maddi, manevi, tarihî, toplumsal gerçekliğiyle irtibatlı görerek bir sentez olarak görebileceğimiz pozisyonları savunanlar da olagelmiştir. Kısmen Heidegger'in ve Nurettin Topçu'nun çabalarını buna örnek verebiliriz. Herhalde Benda aydının ait olduğu toplum ve milletle ilişkisini bütünüyle millî ihtiras kategorisinde görüp eleştirirken ne kadar aşırı bir tutum benimsemiş ise aydınların basit ve kısır, güncel siyasi ihtirasların pençesine düşmelerini eleştirirken de o kadar yerinde bir tutuma işaret etmiştir.

Peki İsmet Özel'in zihnindeki ideal aydın, akademisyen ve entelektüel tipi hakkında sonuç kabilinden ne söylenebilir? Kendisi ile ilgili yapılmış bir yorumdan hareketle düşünecek olursak İsmet Özel'in idealindeki tip kısmen Edward Said'in kısmen de Julien Benda'nın entelektüel tanımlarını kendinde barındırmaktadır (Yusuf, 2005, s. 31-32). Fakat onun entelektüel tipinin Benda'ya uyduğuna dair gerekçelendirme büyük oranda eksik gözükmektedir. Zira bu yoruma göre İsmet Özel'in entelektüeli "Bu dünyaya ait olmayan ebedî hakikat ve adalet gerçekliklerinin bayraktarlığını yapar." görünmektedir. Yine İsmet Özel'in Benda'nın işaret ettiği anlamda "özünde pratik amaçlar gütmeyen faaliyetler yürüten bir sanat, bilimle ya da metafizik bir spekülasyonla ilgilenmekten keyif alan, özetle manevi avantajlara sahip olan" bir entelektüel tipe vurgu yaptığı yorumu da yapılmaktadır. Oysa İsmet Özel'in idealize ettiği düşünsel etkinliğinin doğrudan bu dünyadaki kurulu düzeni, statükoyu hedef aldığı hatırlanacak olursa bu yorumların tam tersi istikamette sonuçlara varmak mümkün olur. Zira İsmet Özel kendisinin de ifade ettiği üzere "yürürlükteki mekanizmayı hedef almayan her türden bilim, sanat ve felsefe uğraşısını bir tür bilinç sapması" olarak görmektedir. İsmet Özel'in Benda'nın çizdiği aydın portresini benimsemeyişinin bir diğer gerekçesi, Benda'nın millî, vatanperver duyguları ihtiras kabilinden görüp aydınların ihanetinin sebebi olarak zikretmesi, buna bağlı olarak evrensele değil de tikele bağlı olan aydınların milletleri şiir, efsane gibi kendilerini başkalarından ayıran özellikleri itibarıyla bir kendilik bilinci geliştirmeye çalışmakla nitelemesidir. Bu durumda millîliğe yaptığı vurgu İsmet Özel'in aydınını olsa olsa Benda'nın ihanet içindeki aydınlar kategorisine sokacaktır. İsmet Özel'in entelektüelini düşünebileceğimiz başka bir entelektüellik bağlamı, işaret edildiği üzere Said'in çizdiği çerçevedir. Fakat bu noktada da İsmet Özel için bir parça açıklayıcı olmayan husus Said'in evrensel değerlere yaptığı vurgudur. İsmet Özel'in pek çok metninden evrensel olarak sunulan değerlere yönelik bir kuşku ve sorgulama sezilir. Bu, büyük oranda sunulan değerlerin bizzat kendilerinin değersiz olmalarından ziyade o değerlerin içeriğinin çok değişik ve güçlü araçlarla gidişatı tayin eden egemen güçlerce belirleniyor olmasından ya da söz konusu değerlerin egemen güçlerin yapmak istedikleri şeyler doğrultusunda kullanışlı bir araç hâline gelmelerinden dolayıdır. İsmet Özel olsa olsa idealindeki entelektüel tipinin sıkı sıkıya bağlandığı İslami hayat görüşünün en hakiki evrensellik oldu- 
ğunu ifade edecektir ki herhâlde bu tutum, bu yaklaşımı "kendilerinin evrensel olduğunu, evrenseli yansıttığını iddia eden partikülarizmler" olarak gören ve eleştiren Benda için olduğu kadar Said için de savunulamayacak bir tutum olacaktır. Fakat benzer şekilde bu durum da İsmet Özel'in entelektüelinin bir anda adalet ve hakkaniyet gözetmeyen, en temel insani durumlara ilişkin sorgulamalar yapmaksızın belirli bir zaman ve mekânda tahakkuk etmiş kendi ait olduğu bütüne dair bir tarihsel-toplumsal gerçekliği ne pahasına olursa olsun savunduğu anlamına gelmez. Biz bunu en çok onun Karacaoğlan'ın “Üryan geldim gene üryan giderim" dizesiyle başlayan şiirine ilişkin yorumunda görürüz. İsmet Özel bu şiiri, Karacaoğlan'ın, tebaası olduğu Osmanlı devlet sisteminin kendi zamanındaki zirve noktasında ulaştığı konuma ilişkin bir eleştirisi olarak yorumlar. İsmet Özel'in entelektüel tipinin Edward Said'in çerçevesini çizdiği anlamdaki entelektüelden ya da akli ve ahlaki bakımdan sorumluluğunu yerine getiren entelektüellerden ayrışır gibi durduğu bir başka nokta daha vardır. Bu da entelektüellerin kısmen halk arasında kısmen de egemenler arasında genel olarak kullanılan bazı tanımlamalara şüpheli yaklaşması gerekirken bu tavrı terk ederek genel koroya dâhil olmaları ve "onlar"ın "biz"i tehdit ettiği gibi gitgide pekişen bir duyguya katılmalarıdır (Said, 1995, s. 45). Benzer şekilde E. Said entelektüelin ana rolünün normlara ve hâkim jargona karşı olmak olduğu, normların millet tarafından oluşturulduğu, milletin ise zafer ve otoritenin, entelektüel sorgulama ve yeniden incelemenin değil, sadakat ve itaatin peşinde olduğu fikriyle temellendirirken de İsmet Özel'den ayrı bir yere düşmüş olur. Aslında herkes bir bakıma kendi şartlarının arkasından konuşmaktadır. Benda bu yüzyılın başında hâlâ tam aşılamamış olan Avrupamerkezci bir tavırla entelektüelin evrensel değerlere bağlıığından söz ederken aklında Avrupa'yı bulunduruyordu. Benzer şekilde Said'in entelektüelin milletçe oluşturulmuş normlara muhalefetini öne çıkarmasında da onun kendi yersiz yurtsuzluğunu, sürgünlüğünü, marjinalliğini dikkate almak zorundayız. Said'de şık duran kelimenin hakiki anlamındaki yersiz-yurtsuzluk ve bundan kaynaklanan evrensellik İsmet Özel'in idealindeki entelektüel tip için anlamsız olabilir. Dolayısıyla İsmet Özel'e göre her bir aydın ve entelektüelin içinde bulunduğu yer, yurt ve şartlar da kendine özgüdür. Bugünkü sorun herkesin, hemen hemen bütün entelektüellerin yaptığı gibi kendisini kuşatan şartların farkında olup bir zeminden hareketle konuşmaktansa bu şartlara bigâne kalarak çok genel bir üslupla, sanki bir dünya vatandaşı edasıyla konuşmasıdır. Kendi şartlarımızın kavranmadığı bir durumda her türden tarihe dönüş de her türden bir gelecek kurgusu da anlamsız bir çaba olarak kalır. İsmet Özel, E. Said'in entelektüeli iki arada bir derede olan, tam olarak ne bir tarafa ne de diğer tarafa da ait olamayan bir sürgün olarak gören yaklaşımından da ayrı düşer. Zira daha yazın hayatının başından itibaren bir siperden söz eden birisinin düşünen kimseye ilişkin böyle bir belirsizliği olumlu görebileceğini söylemek mümkün değildir. İsmet Özel, entelektüele, mensup olduğu toplumun yaşadığı hayati bir kriz anını imleyen tarihsel bir eşikte, elin sürekli tetikte olduğu bir teyakkuz hâlinde bulunma ve mensup olduğu millet adına konuşma vazifesi yükler. İsmet Özel'in entelektüel tipi, Said'in dediği anlamda entelektüel üzerinde baskı kuran engellere direnmesi anlamında da kendi bireysel ve bağımsız entelektüel kimliğine sahip görünür. Ne var ki İsmet Özel'in hem mevcut aydın ve entelektüellere yönelik eleştirileri hem de çerçevesini çizmeye çalıştığı aydın ve entelektüel tipi yeterli ilgiyi görmüş değildir. Bunda kısmen bir miktar eskimedikçe ve tarihsel nitelik kazanmadıkça herhangi bir konuyu inceleyemeyen, incelemekten imtina eden, Said'in de işaret ettiği anlamda daha çok "ihtiyatlı bir bürokrat" tarzında yazıp çizen mevcut akademik geleneğin de rolü vardır. Oysa aydın ve entelektü- 
ellere yönelik bu ve benzeri türden eleştirilere, yeni tanım ve çerçevelere Türkiye'deki ilmî, fikrî, felsefi, entelektüel hayatı ciddiye alıyorsak oldukça fazla ihtiyaç bulunmaktadır. Zira eğer memleketin entelektüellerinin önünde "marjinalliklerinin sonucu olarak umutsuz bir güçsüzlük duygusuna kapılma ya da kendi başlarına sorumsuzca önemli kararlar veren düzen adamlarından oluşan görece küçük bir gruba mensup olup kurumların, şirketlerin ya da hükûmetlerin safına katılma" seçeneklerinden (Said, 1995, s. 36) farklı bir imkân olacaksa bu ancak böyle sorgulamalarla ortaya çıkacaktır.

\section{Kaynakça/References}

Arslan, A. (2002). Aydınlar, entelektüeller ve müminler. Cogito, 31, 201-213.

Aydın, M. (2005). Aydınlar ve günümüzdeki işlevleri. K. Çağan (Ed.), Entelektüel ve iktidar içinde (s. 45-71). Ankara: Hece Yayınları.

Batuhan, H. (2002). Entelektüel kavramı üzerine. Cogito, 31, 94-102.

Benda, J. (2006). Aydınların ihaneti (Çev. C. Soydemir). İstanbul: Doğu-Batı Yayınları.

Chomsky, N. (1994). Modern çağda entelektüellerin rolü (Çev. S. Ayaz). İstanbul: Pınar Yayınları.

Chomsky, N. (2011). Entelektüellerin sorumluluğu (Çev. N. Ersoy). İstanbul: Bgst Yayınları.

Çağan, K. (2005a). Entelektüel imgesi üzerine. K. Çağan (Ed.), Entelektüel ve iktidar içinde (s. 9-22). Ankara: Hece Yayınları.

Çağan, K. (2005b). İktidarla imtihan süreçlerinde entelektüelin durumu. K. Çağan (Ed.), Entelektüel ve iktidar içinde (s. 155-176). Ankara: Hece Yayınları.

Çağan, K. (2005c). Yerli entelektüelin rol ve kimlik bilinci -S. F. Ülgener, C. Meriç ve Ş. Mardin'in düşünceleri ekseninde-. K. Çağan (Ed.), Entelektüel ve iktidar içinde (s. 309-326). Ankara: Hece Yayınları.

Çetinsaya, G. (2014). Büyüme, kalite, uluslararasılaşma: Türkiye yüksek öğretimi için bir yol haritası. Ankara: YÖK.

Demiralp, O. (2002). Entelektüeller ve aydınlar. Cogito, 31, 121-132.

Fazlıoğlu, İ. (2006). Yeni bir medeniyet, yeni bir teo-ontoloji. Anlayış Dergisi, 32.

Fazlıoğlu, İ. (2008). Düşünce saksıda yeşerir mi? Anlayış Dergisi, 61.

Fazlıoğlu, İ. (2013). İslam âlemi önce geçmişini bulmalıdır. Anlayış Dergisi, 6.

Foucault, M. (2000). Entelektüelin siyasi işlevi (Çev. I. Ergüden, O. Akınhay \& F. Keskin). İstanbul: Ayrıntı Yayınları.

Furedi, F. (2014). Nereye gitti bu entelektüeller? (Çev. A. E. Koca). Ankara: Atıf Yayınları.

Genç, E. (2006). Sosyolojik açıdan entelektüel kavramlaştırmaları (Yayımlanmamış doktora tezi). Ankara Üniversitesi Sosyal Bilimler Enstitüsü, Ankara.

Gramsci, A. (1983). Aydınlar ve toplum: (Denemeler) (Çev. V. Günyol, F. Edgü \& B. Onaran). İstanbul: Çan Yayınları.

Gramsci, A. (2003). Hapishane defterleri: Felsefe ve politika sorunları (Çev. A. Cemgil). İstanbul: Belge Yayınları.

Heidegger, M. (2002). Alman üniversitesinin kendini beyanı. A. Demirhan (Der.) Heidegger ve nazizim içinde (s. 40-50). Ankara: Vadi Yayınları.

Keskin, F. (2000). İktidar, hakikat ve entelektüelin siyasi işlevi. F. Keskin (Ed.), Entelektüelin siyasi işlevi (Çev. I. Ergüden, O. Akınhay \& F. Keskin) içinde (s. 13-29). İstanbul: Ayrıntı Yayınları.

Konuk, O. (2005). Modern entelektüelin doğuşu. K. Çağan (Ed.), Entelektüel ve iktidar içinde (s. 73-86). Ankara: Hece Yayınları. 
Le Goff, J. (1994). Orta Çağ'da entelektüeller (Çev. M. A. Kılıçbay). İstanbul: Ayrıntı Yayınları.

Lilla M. (2002). Syrakusa'nın çekiciliği. Cogito, 31, 136-150.

Maclntyre, A. (2006). The end of education: The fragmentation of the American university. Commonweal, CXXXIII(18), 1-4.

Menteş, A. (2000). Yeniversite-bilim kurumlaşmasında günümüz için bir perspektif. İstanbul: Metis Yayınları.

Murat, A. (2005). Düşünmenin Doğulu ve Batılı biçimlerinden bahsedilebilir mi? K. Çağan (Ed.), Entelektüel ve iktidar içinde (s. 261-269). Ankara: Hece Yayınları.

Özel, İ. (1999a). Sorulunca söylenen. İstanbul: Şule Yayınları.

Özel, İ. (1999b). Tahrir vazifeleri. İstanbul: Şule Yayınları.

Özel, İ. (2000a). Zor zamanda konuşmak. İstanbul: Şule Yayınları.

Özel, İ. (2000b). Bilinç bile ilginç. İstanbul: Şule Yayınları.

Özel, İ. (2005). Of not being a jew. İstanbul: Şule Yayınları.

Said, E. (1995). Entelektüel (Çev. T. Birkan). İstanbul: Ayrıntı Yayınları.

Said, E. (2002). Yazar ve entelektüellerin kamusal rolü (Çev. E. G. Atıcı). Cogito, 31, 37-57.

Sartre, J. P. (2014). Aydınlar üzerine (Çev. A. Bora). İstanbul: Can Yayınları.

Schopenhauer, A. (2008). Üniversitelerde felsefe üzerine (Çev. A. Aydoğan). Üniversiteler ve felsefe içinde (s. 37-125). İstanbul: Say Yayınları.

Şan, M. K. (2005). Türk aydınının soy kütüğü üzerine değerlendirmeler. K. Çağan (Ed.), Entelektüel ve iktidar içinde (s. 271-307). Ankara: Hece Yayınları.

Tachau K. H. (2006). Approaching medieval scholars' treatment of cognition. In M. C. Pacheco, \& J. F. Meirinhos (Eds.), Intellect and imagination in medieval philosophy (pp. 1-34). Turnhout: Brepols.

Topçu, N. (1998a). Ahlak nizamı. İstanbul: Dergâh Yayınları.

Topçu, N. (1998b). Türkiye'nin maarif davası. İstanbul: Dergâh Yayınları.

Yusuf, S. (2005). Bir masal İsmet Özel'i. İstanbul: Şule Yayınları. 